VAN WEEZEL, Alex "Sobre la necesidad de un cambio de paradigma en el derecho sancionatorio administrativo".

Polít. crim. Vol. 12, № 24 (Diciembre 2017), Art. 9, pp. 997-1043.

[http://www.politicacriminal.cl/Vol_12/n_24/Vol12N24A9.pdf]

\title{
Sobre la necesidad de un cambio de paradigma en el derecho sancionatorio administrativo
}

\section{On the need of a paradigm change in punitive administrative law}

\author{
Alex van Weezel \\ Profesor de Derecho Penal \\ Pontificia Universidad Católica de Chile \\ avw@uc.cl
}

\section{Resumen}

El problema de las relaciones entre el derecho sancionatorio administrativo y el derecho penal no está resuelto en el ordenamiento chileno. El trabajo esboza una propuesta para avanzar hacia una convivencia razonable de las respectivas potestades sancionatorias. Tras una breve introducción a la luz de la doctrina más reciente de la Corte Suprema, se pasa a la observación de las diferencias sustanciales que exhiben de lege lata el derecho sancionatorio administrativo y el derecho penal. Esta observación da sustento a la tesis de que la equiparación sustancial del derecho sancionatorio administrativo al derecho penal ha fomentado una expansión del primero que se traduce en su omnipresencia y en la severidad de las sanciones que autoriza a aplicar, mientras por otro lado se aboga con buenos argumentos por su emancipación de las "garantías penales". El autor propone superar este dilema mediante una configuración diferente de las sanciones administrativas. El trabajo concluye con una exposición sumaria de las características generales de un derecho sancionatorio administrativo ajustado a sus límites y finalidad.

Palabras clave: Derecho administrativo sancionador, derecho sancionatorio, garantías penales, ius puniendi, administrativización del derecho penal, potestades sancionatorias, enforcement, debido proceso sancionatorio.

\begin{abstract}
The relationships between punitive administrative law and criminal law are an unresolved issue in the Chilean legal system. This paper delineates a proposal to move towards a reasonable coexistence of both punitive powers. First, there will be a brief introduction into the most recent doctrine adopted by the Supreme Court, and then the substantial differences between punitive administrative law and criminal law from a lex lata perspective will be observed. The previous observation provides support to the thesis by which a substantial convergence from punitive administrative law to criminal law has fostered an expansion of the first one, which has translated on its omnipresence and on the severity of the penalties it authorizes. This, while on the other hand, an emancipation from criminal law safeguards has been advocated with solid arguments. The author suggests to overcome this dilemma by
\end{abstract}


VAN WEEZEL, Alex "Sobre la necesidad de un cambio de paradigma en el derecho sancionatorio administrativo".

means of a different configuration of administrative sanctions. The work concludes with a brief exposition of the general characteristics of a punitive administrative system which adjusts to its limits and purpose.

Key words: Punitive administrative law; punitive law; criminal safeguards; punitive power; convergence between punitive administrative law and criminal law; sanctioning powers; enforcement; punitive due process.

\section{Introducción}

¿Corresponde al régimen de sanciones impuestas por la administración el mismo estatuto constitucional de garantías que se reconoce al régimen de las sanciones penales, o al menos un estatuto muy similar?

El solo hecho de que esta pregunta se formule con renovada actualidad y dé lugar a publicaciones y coloquios científicos es muy ilustrativo, pues el asunto parece estar resuelto desde hace tiempo en el ordenamiento chileno, cuando menos desde la sentencia del Tribunal Constitucional recaída en el Rol 244 (1996), cuyo criterio central es reiterado entre muchos otros- en los Roles 480, 1518, 2346, 2648 y, paradigmáticamente, en el Rol 2682 (2014): "Los principios inspiradores del orden penal contemplados en la Constitución Política de la República han de aplicarse, por regla general, al derecho sancionatorio administrativo, puesto que ambos son manifestaciones del ius puniendi propio del Estado"1. En algunas sentencias se sustituye la expresión "por regla general" por la frase "con matices", que viene a significar lo mismo ${ }^{2}$.

Hace solo algunos meses, en el Rol 2922 (2016) -un caso sobre determinación y proporcionalidad de la sanción administrativa-, el Tribunal Constitucional resolvió que "para el ejercicio de la potestad sancionadora administrativa, los órganos dotados de ius puniendi deben sujetarse a ciertos límites impuestos objetivamente por el legislador para efectos de la ponderación de la sanción"3. Incluso el voto disidente, que estuvo por rechazar el requerimiento, comparó la determinación legal de la multa administrativa cuestionada con el estándar de determinación de las sanciones penales de multa para concluir a fortiori que, en ambos casos, serían admisibles las multas indexadas al valor del objeto del ilícito:

\footnotetext{
${ }^{1}$ STC Rol N 2682 (2014), cons. $11^{\circ}$.

${ }^{2}$ La relevancia de este criterio jurisprudencial es grande, pues nunca se ha considerado concluyente el tenor del artículo 20 del Código Penal. Son bien conocidas las posiciones tradicionales en Chile en torno a este precepto: desde la opinión de NOVOA MONREAL, Eduardo (Curso de Derecho Penal Chileno, I, Santiago: Editorial Jurídica de Chile, reimpresión de la $3^{a}$ ed. de 1960, 2005, pp. 39 y ss.), para quien el legislador habría zanjado el problema de la naturaleza de las sanciones administrativas ("no se reputan penas", es decir, no son penas), hasta el planteamiento de CURY, Enrique (Derecho Penal, Parte General, Santiago: Ediciones Universidad Católica de Chile, $7^{\text {a }}$ ed. 2005, pp. 107 y ss.), para quien la expresión revelaría precisamente que se trata de penas que, para ciertos efectos, no serían consideradas como tales. Los diferentes puntos de vista en la doctrina penal pueden consultarse en las referencias de COUSO, Jaime y HERNÁNDEZ, Héctor, Código Penal Comentado. Parte General, Santiago: LegalPublishing, 2011, p. 447.
}

${ }^{3}$ STC Rol N 2922 (2016), cons. 27․ 
Polít. crim. Vol. 12, No 24 (Diciembre 2017), Art. 9, pp. 997-1043.

[http://www.politicacriminal.cl/Vol_12/n_24/Vol12N24A9.pdf]

"Si aplicamos los criterios del derecho penal al derecho administrativo sancionador, con matices, no resulta razonable tener una jurisprudencia indulgente con la decisión que adopta el legislador [penal] ... y, por el contrario, ser severos con el mismo ejercicio del legislador en materia sancionatoria [administrativa,] si lo único que está en juego [en esta última] son bienes jurídicos de menor entidad". ${ }^{4}$

La tesis que se expone a continuación consiste en que los "matices" son, de lege lata, de tal envergadura, que el criterio rector del Rol 244 (1996) no es sostenible en sus fundamentos. Conforme al derecho vigente en Chile, el derecho sancionatorio administrativo solo exhibe un cierto parecido externo con el derecho penal. A esta tesis siguen otras tres, como consecuencia y complemento. En primer lugar, si el afán por extender las garantías penales al derecho sancionador de la administración es tan intenso, ello se debe a que este ha adquirido dimensiones monstruosas. Esta situación justifica plenamente las demandas por un régimen de garantías que resulte acorde con la omnipresencia y gravedad de las potestades sancionatorias que la ley ha entregado a las autoridades dependientes del ejecutivo. En segundo término, del reconocimiento de las sustanciales diferencias que separan las sanciones administrativas de las penales debería seguirse coherentemente una reformulación radical del derecho sancionatorio administrativo, con el fin de ajustar su instrumentario a las finalidades y limitaciones que le son propias. El afán por extender al derecho sancionatorio administrativo las garantías penales es, en tercer lugar, la consecuencia de un problema autogenerado por la tesis de la identidad sustancial entre el derecho sancionatorio administrativo y el derecho penal: si ambos son sustancialmente lo mismo y para ambos se promete la aplicación, sustancialmente, de las mismas garantías, ¿qué razón habría para no configurar el derecho sancionatorio administrativo como un segundo derecho penal?

Con otras palabras, el problema de las relaciones entre el derecho sancionatorio administrativo y el derecho penal no está en absoluto resuelto en el ordenamiento chileno. Aquí se esboza una propuesta para avanzar hacia una solución que se estima razonable y necesaria si se trata de tomar en serio los fines de las respectivas potestades sancionatorias. Este esbozo comprende una breve introducción al problema que se basa en una sentencia relativamente reciente de la Corte Suprema (1); la observación de las diferencias sustanciales que, de lege lata, exhiben el derecho sancionatorio administrativo y el derecho penal (2); la constatación del dilema en que se encuentra actualmente el ordenamiento chileno y la necesidad de superarlo (3 y 4), y un esbozo de las características de un derecho sancionatorio administrativo futuro, ajustado a sus límites y finalidad (5).

Conviene advertir desde un comienzo que el derecho sancionatorio administrativo es solo una parte del derecho sancionador no penal, caracterizado al menos teóricamente ${ }^{5}$ por que no se imponen sanciones privativas de libertad. Hay importantes ámbitos de derecho sancionatorio no penal que no son derecho sancionatorio administrativo, como el derecho de defensa de la competencia, una parte del derecho contravencional tributario y, en gran

\footnotetext{
${ }^{4}$ STC Rol No 2922 (2016), cons. 56 del voto disidente de los ministros señores Carmona, García y Hernández.

${ }^{5}$ Sobre las razones para relativizar esta distinción véase más adelante en el texto, sección 2.1.
} 
VAN WEEZEL, Alex "Sobre la necesidad de un cambio de paradigma en el derecho sancionatorio administrativo".

medida, el derecho de policía local. Aquí nos referiremos principalmente a las sanciones que no son impuestas por un tribunal, es decir, a aquellas donde quien investiga y formula los cargos es la misma autoridad que luego juzga y sanciona -aunque haya diferencias jerárquicas al interior de un mismo servicio-. Se ha tenido además especialmente presente el denominado derecho administrativo sancionador regulatorio.

\section{Un caso sintomático}

Hace poco más de dos años, la Corte Suprema tuvo que decidir un caso en donde la principal discusión consistía en la eventual aplicación de "principios penales" al derecho sancionatorio administrativo ${ }^{6}$. Una persona natural fue sancionada en sede administrativa por infracciones a la Ley $\mathrm{N}^{\circ} 18.045$ sobre Mercado de Valores; la sanción, impuesta por la Superintendencia de Valores y Seguros (SVS), consistió en el pago de una sustanciosa multa. Dentro del plazo legal, el sancionado dedujo reclamación ante el tribunal competente. El procedimiento de reclamación siguió su curso en diversas instancias hasta que, contra la sentencia de la Corte de Apelaciones de Santiago, se dedujeron recursos de casación en la forma y en el fondo. Durante la tramitación de estos recursos, que la Corte Suprema acabaría por rechazar, falleció la persona multada. Cuando el Fisco instó por el pago de la multa a los herederos, éstos se negaron a efectuarlo aduciendo, como argumento principal, que la multa constituía una sanción administrativa y, como tal, quedaba sujeta al principio de personalidad de las penas. Sostuvieron que si bien conforme al artículo 20 del Código Penal las sanciones administrativas "no se reputan penas", ellas son manifestación del ius puniendi estatal y por tanto deben sujetarse a unos mismos principios, al menos en términos generales. El carácter personalísimo de la responsabilidad penal -también denominado "personalidad de las penas"- sería uno de esos principios. Por lo tanto, la multa administrativa no sería transmisible a los herederos, al menos mientras no haya sido impuesta a través de una resolución firme o ejecutoriada.

A la vista de la jurisprudencia unánime de los tribunales superiores de justicia y del Tribunal Constitucional, era esperable que la Corte Suprema -tal como por lo demás había hecho unos pocos meses antes en un caso similar ${ }^{7}-$ considerara improcedente la transmisibilidad de la multa administrativa cuando, a la fecha de la muerte del sancionado, se encontraba aún pendiente su impugnación. Lo interesante es que ocurrió todo lo contrario. El fallo, una decisión divida de tres contra dos, consideró que la multa administrativa -a diferencia de la multa penal- es transmisible aunque esté pendiente su impugnación.

En el considerando $8^{\circ}$ de la sentencia de casación, el fallo destaca que toda la discusión gira en torno a la eventual aplicación de los principios penales a la potestad sancionatoria de la administración, es decir, a una posible "relación de semejanza" entre la sanción administrativa y la sanción penal. El considerando $9^{\circ}$ realiza en lo sustancial tres operaciones para clarificar esta cuestión: (i) destacar que la sanción administrativa se impone mediante un "acto administrativo"; (ii) recordar la doctrina jurisprudencial sobre

\footnotetext{
${ }^{6}$ SCS 30.X.2014, Rol N ${ }^{\circ} 1079-2014$.

${ }^{7}$ En la causa $\mathrm{Rol} \mathrm{N}^{\circ} 1855-2013$.
} 
Polít. crim. Vol. 12, No 24 (Diciembre 2017), Art. 9, pp. 997-1043.

[http://www.politicacriminal.cl/Vol_12/n_24/Vol12N24A9.pdf]

las relaciones entre derecho sancionatorio administrativo y derecho penal, enfatizando la existencia de "matices", y luego (iii) desarrollar in extenso tales matices y diferencias entre los regímenes jurídicos de ambas clases de sanción.

El desarrollo de las diferencias entre ambos regímenes comienza con un ejemplo particularmente gráfico, el de la exigencia de tipicidad o determinación. Citando un fallo anterior de la misma Corte $^{8}$, afirma que "la naturaleza de las contravenciones administrativas (...) hace imposible su síntesis descriptiva en un precepto general como lo es una Ley". Es notable el carácter categórico de esta afirmación, afincada por su autor en la naturaleza misma de las $\operatorname{cosas}^{9}$. La determinación del tipo infraccional debe ser entonces relajada, "lo que se explica y justifica por los diferentes aspectos y fines que determinaron la elección que hizo el legislador al optar por sancionar administrativamente y no penalmente un determinado comportamiento".

La consideración más importante en el desarrollo de las diferencias es la siguiente: la aplicación del derecho sancionatorio administrativo no puede contravenir los fines que tuvo en vista el legislador al momento de optar por sancionar un ilícito conforme al derecho penal o al derecho administrativo. En sus propios términos:

"El recurso a los principios del derecho penal no debe llevar a la desnaturalización de la potestad administrativa sancionatoria, de tal manera que con ello se desconozca la intención y fines que el legislador tuvo en consideración al momento de recurrir a ella para dotar de eficacia a las instituciones jurídicas que establece con ocasión de la regulación de las distintas materias". ${ }^{10}$

La sanción administrativa tiene por objeto dotar de eficacia a una determinada regulación.

El planteamiento del fallo resulta, entonces, claro y contundente. Para dotar de eficacia a una determinada regulación, el legislador opta por entregar a la administración la potestad de imponer sanciones a través de actos administrativos. El régimen jurídico de estas sanciones se aparta del régimen propio de las sanciones penales. Si se aplicara a las primeras el régimen de estas últimas, se "desnaturalizaría" la potestad administrativa sancionatoria.

Con los elementos anteriores, el fallo de mayoría resuelve coherentemente que:

\footnotetext{
${ }^{8}$ SCS 25.IV.2010, Rol N² 2968-2010 (cursivas añadidas).

9 Ella reproduce literalmente lo ya resuelto por el mismo tribunal en SCS Rol N ${ }^{\circ} 2.518-2010$ y Rol $\mathrm{N}^{\circ}$ 10.045-2011. El Tribunal Constitucional hace suya esta afirmación en STC Rol N ${ }^{\circ} 2264$ (2013), cons. 38 (aunque el argumento ya se encontraba en la disidencia del fallo correspondiente al Rol 1518 de 2010).

${ }^{10}$ SCS 30.X.2014, Rol 1.079-2014, cons. $9^{\circ}$ (cursivas añadidas). En otro pasaje del mismo considerando se afirma que "dicha carencia legislativa [de un régimen general para el derecho sancionatorio administrativo] y el común origen de ambas sanciones no autorizan para aplicar de manera automática las normas y principios propios del derecho penal al derecho administrativo sancionador, sino que tal aplicación debe efectuarse dentro de los márgenes del procedimiento administrativo en general y del sancionatorio en particular, sin perder de vista el contexto que tuvo en vista el legislador para optar por una u otra sanción”.
} 
VAN WEEZEL, Alex "Sobre la necesidad de un cambio de paradigma en el derecho sancionatorio administrativo".

(a) Si la sanción administrativa se impone a través de un acto administrativo, éste ha de regirse por el artículo $3^{\circ}$ de la Ley $\mathrm{N}^{\circ} 19.880$, conforme al cual los actos administrativos "gozan de una presunción de legalidad, de imperio y exigibilidad frente a sus destinatarios, desde su entrada en vigencia, autorizando su ejecución de oficio por la autoridad administrativa, salvo que mediare una orden de suspensión dispuesta por la autoridad administrativa dentro del procedimiento impugnatorio o por el juez, conociendo por la vía jurisdiccional". Y también por el inciso $1^{\circ}$ del artículo 51 de la misma ley: "Los actos de la Administración Pública sujetos al Derecho Administrativo causan inmediata ejecutoriedad, salvo en aquellos casos en que una disposición establezca lo contrario o necesiten aprobación o autorización superior". Con otras palabras, la multa impuesta existe y es exigible desde que se perfecciona la resolución administrativa que la impone, aunque pueda suspenderse su ejecutividad por otra disposición legal o por orden de un tribunal.

(b) Por otro lado, no obsta a la ejecutoriedad del acto administrativo sancionatorio el carácter personalísimo de la responsabilidad penal, pues ambos sistemas sancionatorios están sujetos a regímenes diversos, determinados por los fines que tuvo en vista el legislador al momento de optar por uno u otro. El derecho sancionatorio administrativo existe para ciertos fines y debe ser eficaz para alcanzarlos. En este caso se trataría, al menos en parte importante, de privar al sancionado del beneficio que le trajo el abuso de una posición especial respecto del emisor de valores. Para el derecho sancionatorio administrativo es irrelevante la muerte del condenado, pues el beneficio obtenido es transmisible y, por lo tanto, debe serlo también la sanción. Si esto repugna a la lógica del derecho penal, pues afecta uno de sus principales principios -el de personalidad de las penas-, peor para esa lógica.

\section{El verdadero rostro del derecho sancionatorio administrativo}

El fallo referido en el apartado anterior proyecta algo más que una sombra de duda sobre el lenguaje de las declaraciones de principios, conforme al cual el derecho sancionatorio administrativo sería el "hermano pequeño" del derecho penal, y por lo tanto existiría más que un mero parecido externo entre ellos. Esta sospecha resulta confirmada cuando se examinan las características que el derecho sancionatorio administrativo exhibe de lege lata en el ordenamiento jurídico chileno, pues entonces se devela una inconsistencia radical: las sanciones administrativas son de lege lata algo distinto del ius puniendi estatal ${ }^{11}$, pero existe un afán -ideológico o pragmático-de asimilarlas a las sanciones penales.

\subsection{La privación de libertad: un criterio distintivo de alcance limitado}

En el debate reciente se ha hecho habitual cifrar la distinción entre ambas potestades sancionatorias en la posibilidad, exclusiva de la potestad penal, de imponer sanciones privativas de libertad. En el ya citado Rol 2922 (2016), los ministros disidentes argumentan, por ejemplo, que "el monto de una multa es irrelevante en la valoración de los

\footnotetext{
${ }^{11}$ Con ello abandono la opinión expresada en VAN WEEZEL, Alex, Delitos Tributarios, Santiago: Editorial Jurídica de Chile, 2007, p. 24.
} 
Polít. crim. Vol. 12, No 24 (Diciembre 2017), Art. 9, pp. 997-1043.

[http://www.politicacriminal.cl/Vol_12/n_24/Vol12N24A9.pdf]

bienes jurídicos comparado con la libertad personal" "12. Este punto de vista es en principio correcto, pero insuficiente; mal entendido, podría incluso llevar a una confusión entre la causa y el efecto, y a minimizar indebidamente el carácter aflictivo de las sanciones diversas de la privación de libertad.

Esta insuficiencia del criterio se expresa particularmente en la evolución del régimen de sustitución de la pena de multa en el Código Penal y de las penas alternativas a la privación de libertad. Paralelamente y contraste con estos dos aspectos, resulta ilustrativa la consideración de los apremios personales dispersos en la legislación, cuya aplicación ha dado lugar a una relativamente nutrida y algo controversial jurisprudencia constitucional.

La Ley N²0.587 de 2012 derogó, en efecto, la antigua regla según la cual el no pago de la multa penal conducía a la pena de reclusión por un tiempo máximo de seis meses ("Si el sentenciado no tuviere bienes para satisfacer la multa, sufrirá por vía de sustitución y apremio, la pena de reclusión"). En su lugar, estableció en el mismo supuesto -a saber, cuando el sentenciado carece de bienes para satisfacer la multa- la facultad del tribunal para disponer, por vía de sustitución, una pena de prestación de servicios en beneficio de la comunidad, siempre que el condenado manifieste su acuerdo (artículo $49 \mathrm{CP}$ ). Además se estableció la improcedencia de la multa y su sustitución si de los antecedentes expuestos por el condenado "apareciere la imposibilidad de cumplir la pena" (habría que entender que se trata de la pena sustitutiva, pues si carece de bienes para pagar la multa, procede justamente imponer aquella). En caso de quebrantamiento de la pena sustitutiva, también se concede al tribunal la facultad para revocarla. Y si no la revoca, dispone el inciso final del artículo 49 sexies CP, "podrá ordenar" que se cumpla en un lugar distinto; todo ello sin perjuicio, insiste la ley, de la facultad que tiene el tribunal para considerar simplemente imposible el cumplimiento ${ }^{13}$.

Con este régimen y con el sistema de penas alternativas a la privación de libertad previsto en la Ley $\mathrm{N}^{\circ} 18.216$-la pena de cárcel establecida en la ley se cumple efectivamente solo en el caso de los delitos más graves o de reincidencia múltiple- contrasta la relativa facilidad con que el Código Tributario y ciertas regulaciones sectoriales echan mano de la privación de libertad como forma de apremio personal ${ }^{14}$. Así, por ejemplo, hay apremios personales destinados a obtener el cumplimiento de resoluciones judiciales que condenan al pago de una obligación en el artículo 12 de la Ley $\mathrm{N}^{\circ} 17.322$, sobre normas para la cobranza de cotizaciones, aportes y multas de las instituciones de Seguridad Social; en los artículos 14 y 15 de la Ley $N^{\circ}$ 14.908, sobre Abandono de Familia y Pago de Pensiones

${ }^{12}$ STC Rol N 2922 (2016), cons. 63 del voto disidente de los ministros señores Carmona, García y Hernández (cursivas añadidas).

${ }^{13}$ En la práctica, además, las penas de multa rara vez de imponen cuando son copulativas de una pena privativa de libertad, o bien se tienen por cumplidas en consideración al tiempo que duró la detención o la prisión preventiva del condenado.

${ }^{14}$ Véase FERNÁNDEZ CRUZ, J. A., "Tribunal Constitucional y derecho penal: Un estudio crítico", Estudios Constitucionales, $\mathrm{N}^{\circ} 2$ (2014), pp. 187-238 (pp. 216 y ss.); más en detalle y con un catastro de los numerosos preceptos que establecen esta clase de apremios BOUTAUD, Emilio, Constitucionalidad de los apremios personales en la jurisprudencia del Tribunal Constitucional, Memoria de Prueba para optar al grado de Licenciado en Ciencias Jurídicas y Sociales, Universidad Austral de Chile (sin fecha). 
VAN WEEZEL, Alex "Sobre la necesidad de un cambio de paradigma en el derecho sancionatorio administrativo".

Alimenticias; en los artículos 93 a 96 del Código Tributario, respecto del contribuyente que tuviere obligaciones tributarias impagas o retarda el entero de impuestos sujetos a retención o recargo; en el artículo 32 inciso segundo de la Ley $\mathrm{N}^{\circ}$ 18.695, Orgánica Constitucional de Municipalidades; etc.

También los hay destinados a obtener el cumplimiento de otro tipo de resoluciones judiciales, como el artículo 238 del Código de Procedimiento Civil, tratándose del cumplimiento de resoluciones que no sean sentencias o se encuadren dentro de la hipótesis del artículo 235 del mismo cuerpo legal; el artículo 543 del Código de Procedimiento Civil, respecto del deudor de una obligación de hacer o de una obligación de no hacer cuando ésta se convierta en la de destruir la obra hecha; en el artículo 41 de la Ley $\mathrm{N}^{\circ} 18.287$, respecto del conductor que injustificadamente impide el cumplimiento de la cancelación o suspensión de su licencia decretada por el Juez de Policía Local; en el artículo 292 del Código del Trabajo, respecto del empleador que se niega a dar cumplimiento cabal a la orden de reincorporación de un trabajador, o ante una nueva separación o no pago oportuno y debido de las remuneraciones y demás prestaciones laborales de un trabajador; en el artículo 10 de la Ley $\mathrm{N}^{\circ}$ 20.066, ante el incumplimiento de medidas cautelares o accesorias decretadas en el procedimiento por actos de violencia intrafamiliar no constitutiva de delito; etc.

Pero también hay privaciones de libertad que tienen por objeto sustituir el pago de una multa previamente impuesta o castigar abusos o faltas (los denominados "arrestos disciplinarios"). Así, el artículo 23 de la Ley $\mathrm{N}^{\circ} 18.287$ faculta al juez de policía local para decretar la reclusión o la prestación de servicios en beneficio de la comunidad del condenado a una sanción de multa que no hubiere acreditado su pago. El pago de la multa permite dejar sin efecto la privación de libertad. Una verdadera sanción es la que se impone al litigante beneficiario de pobreza que no paga la multa que se le impuso por estimar el tribunal que procedió con notoria malicia (artículo 591 del Código Orgánico de Tribunales). También pueden considerarse sancionatorios los arrestos contemplados en el Título XVI del Código Orgánico de Tribunales para reprimir o castigar los abusos que se cometieren dentro de la sala de despacho de los jueces de letras y las faltas que se cometieren ante la Corte Suprema y ante las Cortes de Apelaciones, mientras ejercen sus funciones (artículos 530 y 542). Desde luego, también tienen carácter represivo los arrestos militares de hasta dos meses previstos en el Código de Justicia Militar para sancionar administrativamente las faltas de disciplina (artículo 431).

El caso del artículo 169 del Código Sanitario es particularmente ilustrativo ${ }^{15}$. Esta regla, que fue derogada recién en 2014 por la Ley $\mathrm{N}^{\circ}$ 20.724, fue objeto de un interesante fallo de inaplicabilidad del Tribunal Constitucional. En un extenso y razonado voto disidente, los

\footnotetext{
15 “Art. 169.- Si transcurrido el plazo señalado en el artículo anterior, el infractor no hubiere pagado la multa, sufrirá, por vía de sustitución y apremio, un día de prisión por cada décimo de unidad tributaria mensual que comprenda dicha multa. Para llevar a cabo esta medida, el Director del correspondiente Servicio de Salud o del Instituto de Salud Pública de Chile, en su caso, solicitará del Intendente o Gobernador respectivo el auxilio de la fuerza pública, quienes dispondrán sin más trámite la detención del infractor y su ingreso al establecimiento penal respectivo, a cuyo efecto librarán la orden correspondiente en conformidad a las reglas generales, dando cuenta de lo obrado a la autoridad sanitaria".
} 
Polít. crim. Vol. 12, No 24 (Diciembre 2017), Art. 9, pp. 997-1043.

[http://www.politicacriminal.cl/Vol_12/n_24/Vol12N24A9.pdf]

ministros señores Carmona y Fernández estuvieron por rechazar el requerimiento ${ }^{16}$. El voto se hace cargo de diversos aspectos y profundiza en cuestiones fundamentales -como la ejecutoriedad de los actos administrativos sancionatorios-, pero para lo que interesa en este lugar sostiene el argumento ya clásico de que la privación de libertad no es una pena o sanción -se trata de un "arresto"-, debido a que se puede enervar mediante el pago de la $\operatorname{multa}^{17}$.

Sin embargo, también este es el caso de la multa penal, incluso en el régimen más duro anterior a la reforma de 2012. La privación de libertad se encuentra prevista única y exclusivamente para el caso en que el condenado no paga la multa e, incluso más, no la paga porque carece de bienes para satisfacerla, es decir, se encuentra en una situación que en principio no está en sus manos resolver. Lo relevante es lo que ocurre cuando la multa no se paga y, desde este punto de vista, la idea de que en un caso se trata de la sustitución de la sanción y, en el otro, de un simple apremio, carece de sustancia argumental. Aun más, sería un grave error insistir por razones de principio en que la privación de libertad por apremio no puede sustituir a la multa no penal impaga. Ello conduciría -salvo regla expresa en contrario, como existe en materia penal- a que una vez cumplido el plazo máximo del apremio sin que se haya solucionado la multa, el Estado aún podría exigir su pago.

Salvo en cuanto a la duración posible de la privación de libertad, la sustitución de la multa penal y la de otras multas cuya índole extrapenal está fuera de discusión operan de un modo muy similar. Las diferencias de régimen entre ambas clases de sustitución hay que buscarlas fuera de la operatoria de la medida misma, a saber, en el sentido y finalidad de una y otra, que a su vez determinan el órgano competente y el procedimiento, así como los presupuestos sustantivos mediatos -la existencia de un ilícito- para su aplicación.

En síntesis, la modificación radical del régimen de sustitución de la pena de multa establecido en los artículos 49 y siguientes del Código Penal, el hecho de que en la práctica vastos ámbitos del derecho penal -desde luego, prácticamente todos los delitos no violentos- operen con prescindencia de la privación de libertad, y la configuración legal de los apremios personales ante infracciones no penales, permiten concluir que la privación de libertad no funciona por sí sola como criterio distintivo de lo que pertenece al derecho penal. Por las mismas razones, hasta donde alcanzo a ver, nadie ha planteado hasta el momento que se prescinda de las garantías penales cuando se trata de delitos que no contemplan penas privativas de libertad.

Un examen más atento merece en este contexto la idea que subyace a la consideración de la privación de libertad como una sanción incomparablemente más dura que cualquiera otra. De esta idea surge también una cierta tendencia a minimizar la aflictividad de otras privaciones o suspensiones de derechos y de la multa. Y de esta tendencia, a su vez, parece

\footnotetext{
${ }^{16}$ Causa Rol N 1518 (2010).

${ }^{17}$ STC Rol N 1518 (2010): "Se trata de un apremio asociado al cumplimiento de deberes. El arresto busca obligar a determinados individuos a adoptar la conducta socialmente necesaria en un momento dado; es una privación provisional de libertad sujeta al cumplimiento de un acto por parte del arrestado, pues impone al afectado la carga de responder a un deber legal" (cons. $30^{\circ}$ del voto disidente).
} 
VAN WEEZEL, Alex "Sobre la necesidad de un cambio de paradigma en el derecho sancionatorio administrativo".

desprenderse luego que la imposición de una multa apenas tendría carácter sancionatorio o que constituiría un mecanismo de enforcement como cualquier otro. Esta secuencia argumental es desafortunada por diversas razones. En primer lugar, la comparación con la privación de libertad es falaz, pues incorpora de modo subrepticio elementos implícitos y accidentales, como las deplorables condiciones humanas en las cuales se cumplen actualmente en Chile las penas de encierro. En segundo término, pues no hace justicia al impacto que tiene en la existencia personal, por ejemplo, la inhabilitación perpetua o aun prolongada para realizar la actividad profesional para la cual se está capacitado y que ha ocupado la mayor parte de la vida de una persona. La aflictividad de la sanción depende, en una medida que sería erróneo desestimar, de la persona a quien se impone.

Pero la comparación no solo es desafortunada, sino que también podría ser perniciosa, y lo es cuando conduce a desdibujar la naturaleza jurídica de las sanciones, considerándolas una herramienta más en la "caja" de la cual dispone la administración para hacerse obedecer ${ }^{18}$. Así, la sanción administrativa no sería más que un acto administrativo desfavorable para el administrado, como cuando se le niega un permiso o se le impone una exigencia adicional para realizar una determinada actividad económica. Sin embargo, no es así. Las sanciones administrativas no dejan de ser tales por el hecho de que su finalidad y el contexto de su imposición, como se desarrolla en el apartado siguiente, sean distintos de los que caracterizan al derecho penal ${ }^{19}$.

Toda norma jurídica establece, junto a los presupuestos de su aplicación, las consecuencias jurídicas que de ella se siguen. Esta subsunción bajo el "tipo legal" y la realización de la consecuencia jurídica -también llamada "sanción"- corresponden a la estructura general de la imputación como applicatio legis ad factum. Una especie dentro de este género es la imposición de castigos. Las notas que definen esta especie son en parte objeto de discrepancias, pero en todo caso permiten distinguir entre la imputación del daño que da

\footnotetext{
${ }^{18}$ Como sostiene, entre otros, PAREJO, Luciano, "Algunas reflexiones sobre la necesidad de la depuración del status de la sanción administrativa", Revista General de Derecho Administrativo, Vol. 36 (2014), pp. 1-26 (p. 14): la sanción administrativa no sería más que "una técnica más al servicio de la efectividad de las políticas públicas formalizadas en los programas legales a ejecutar por la Administración”.

${ }^{19}$ Fundamental en este sentido ARANCIBIA, Jaime, "El principio de necesidad de la sanción administrativa como potestad de ultima ratio", en: ARANCIBIA, Jaime; ALARCÓN, Pablo, Sanciones Administrativas, Santiago: Thomson Reuters, 2014, pp.129 y ss., quien establece un criterio de "necesidad" de la sanción ante la ineficacia o insuficiencia de las potestades correctivas de prima ratio (pp. 142 y ss.); sin embargo, a mi juicio Arancibia amplía excesivamente los casos de insuficiencia cuando afirma que la sanción sería necesaria respecto de las infracciones graves, que son "aquellas que lesionan un interés social de modo significativo" (p. 143); también asume la distinción SOTO DELGADO, Pablo, "Sanciones administrativas como medidas de cumplimiento del Derecho: un enfoque funcional y responsivo aplicado al régimen sancionatorio ambiental", Ius et Praxis (2016), pp. 201 y ss. En contra de lo sostenido en el texto, LETELIER, Raúl, "Un paso adelante de la Corte Suprema, dos pasos atrás del Tribunal Constitucional: garantías penales y sanciones administrativas", en El Mercurio Legal, 2.XII.2016, quien se pronuncia a favor de un derecho sancionatorio administrativo de prima ratio; refiriéndose a STC Rol № 2922 (2016), señala: "Una de las cosas que más sorprende de esta sentencia (...) es aquella precomprensión de que sancionar es algo excepcional; de que es posible regular mercados monopólicos imponiendo conductas obligatorias, pero entendiendo la sanción a su incumplimiento como una técnica de ultima ratio; de que es posible superar las asimetrías informativas, los negocios extremadamente lucrativos, la especulación irregular, las externalidades negativas mediante una regulación cuyo enforcement sea excepcional o muy limitado”.
} 
Polít. crim. Vol. 12, No 24 (Diciembre 2017), Art. 9, pp. 997-1043.

[http://www.politicacriminal.cl/Vol_12/n_24/Vol12N24A9.pdf]

lugar a la "sanción" de tener que indemnizar los perjuicios, la imputación de un incumplimiento contractual que da derecho a aplicar la "sanción" de cobro de la boleta de garantía, y la imputación de una falta que da paso a la imposición de un castigo. Si la ingente masa de la legislación y reglamentación administrativa ha venido a desdibujar en ciertos ámbitos los límites entre estas tres clases de consecuencias jurídicas, ello constituye un retroceso y no refleja, a mi modo de ver, el panorama general de la legislación chilena.

Dicho de otro modo, la tesis que propone una distinción fundamental entre las sanciones administrativas y las penales -tesis que aquí se suscribe- no requiere negar a las primeras su índole propiamente sancionatoria. Ello justifica que su imposición esté sujeta a un estatuto jurídico que no es el del derecho penal, pero que se distingue del que rige a los actos administrativos no sancionatorios.

\subsection{El fundamento teleológico de la distinción}

La potestad sancionatoria de la administración corresponde a una fase en la implementación de una regulación sectorial y, en definitiva, de las políticas públicas que se plasman en ella. Primero se formula la política pública, que luego se expresa en una ley. La ley normalmente es implementada a través de un reglamento, al que siguen circulares y oficios del servicio encargado de la implementación. Este mismo servicio, u otro relacionado, inicia oportunamente procesos de fiscalización y, en una última etapa, instruye procesos sancionatorios con el fin de dotar de eficacia a la regulación. En esta última etapa suelen establecerse metas de gestión ${ }^{20}$.

El auge del derecho sancionatorio de la administración es consistente con el proceso de materialización o desformalización del derecho que ya observaba Max Weber. Los esfuerzos para que la ley siga configurando de modo eficaz una sociedad crecientemente compleja producen un incremento exponencial de la regulación. Paradójicamente, sin embargo, la ley se vuelve en este proceso cada vez más indeterminada. Como debe lidiar con factores imprevisibles, con estructuras complejas de decisión y un contexto cambiante, el legislador debe limitarse a proponer fines y dejar la elección de los medios a quienes tienen la función de concretar la ley ${ }^{21}$. El derecho de la construcción y el derecho del medio ambiente son claros ejemplos de materialización.

\footnotetext{
${ }^{20}$ Esto se aprecia con mucha claridad cuando el derecho condiciona la persecución penal a la decisión de un órgano administrativo. En estos casos se produce una "administrativización” de la lógica penal, pues el órgano administrativo ve en el derecho penal un mero instrumento para la obtención de objetivos sectoriales. Así ocurre en Chile, por ejemplo, con los delitos tributarios. En el ámbito de la legislación penal relativa al mercado de valores la cuestión ha sido destacada en nuestro país por GARCÍA PALOMINOS, Gonzalo, "Modelo de protección en normas administrativas y penales que regulan el abuso de información privilegiada en la legislación chilena", Política Criminal, Vol. 8, n 15 (2013), pp. 23 y ss.; más en general, COLLADO, Rafael, "De la administrativización del derecho penal a la criminalización del derecho administrativo", en: ARANCIBIA/ALARCÓN, Sanciones Administrativas, cit. nota n 19, pp. 541 y ss. (pp. 545-552).

${ }^{21}$ Cfr. HABERMAS, Jürgen, "Recht und Moral", en: Faktizität und Geltung. Beiträge zur Diskurstheorie des Rechts und des demokratischen Rechtsstaats, Frankfurt a. M.: Suhrkamp, 1992, p. 542; TEUBNER, Günther, Recht als autopoietisches System, Frankfurt a. M.: Suhrkamp, 1989, pp. 102 y ss.
} 
VAN WEEZEL, Alex "Sobre la necesidad de un cambio de paradigma en el derecho sancionatorio administrativo".

Como consecuencia de este proceso - que significa más control, más dirección normativa en el nivel infralegal para la ejecución de los fines plasmados en la legislación- surgen una administración y una judicatura con amplios espacios de autonomía, lo que obliga, por ejemplo, a plantear de un modo diferente las relaciones entre la potestad legislativa y las potestades normativas de la administración, desechando la lógica de los ámbitos exclusivos y enfatizando la idea de colaboración. Por las mismas razones, cuando la doctrina administrativista se ocupa de las garantías que deben respetarse en la imposición de sanciones suele pensar en garantías procesales $y$ no sustantivas. Esta "procedimentalización" de los resguardos es una consecuencia típica de la materialización o desformalización del derecho.

La sentencia del Tribunal Constitucional recaída en la causa Rol 2264 (2013) razona desde esta misma lógica:

"Las superintendencias son órganos de la Administración del Estado encargados de fiscalizar a sujetos privados que llevan a cabo actividades particularmente relevantes. Se distinguen por estar dotadas de fuertes atribuciones (normativas, fiscalizadoras, sancionadoras); y por controlar a sujetos acotados. Estos órganos no han sido creados por el legislador en todas las áreas de la economía, sino solo donde hay bienes jurídicos significativos comprometidos para la sociedad. De ahí que existan en el mercado de capitales (...); en el ámbito de los servicios concesionados (...); en el de la seguridad social (...); y, finalmente, están las que operan en sectores sensibles". 22

Por eso, concluye el fallo citado en esta parte, las superintendencias deben tener la facultad de castigar no solo el incumplimiento formal de la ley, sino también el de sus propias instrucciones e indicaciones, que tienen carácter constitutivo y cuyo contenido solo requiere enmarcarse en términos generales en el marco de la legislación aplicable.

Bajo estas premisas, resulta perfectamente comprensible que las potestades sancionatorias del ejecutivo hayan experimentado un auge desconocido hasta la fecha, y existen abundantes indicios de que esta tendencia se mantendrá en el futuro.

Pero todo esto poco o nada tiene que ver con la potestad punitiva del Estado, que es el procesamiento de la culpabilidad por un injusto de ciertas características. El derecho penal es retrospectivo - sin perjuicio de que por añadidura pueda cumplir funciones preventivas-, mientras que el derecho sancionatorio administrativo es prospectivo, es decir, se legitima con miras al buen funcionamiento de un sector, atiende a la evitación o control de fuentes de peligro y, por lo mismo, es particularmente receptivo respecto de consideraciones prevencionistas o de disuasión ${ }^{23}$. Así se reconoce ampliamente desde la dogmática administrativa $\mathrm{y}$ ha quedado plasmado en la jurisprudencia reciente del Tribunal

\footnotetext{
${ }^{22}$ STC Rol N 2264 (2013), cons. $9^{\circ}$ (cursivas añadidas).

${ }^{23}$ En similares términos, si bien desde una perspectiva cercana a la filosofía, LONDOÑO, Fernando, "Tipicidad y legalidad en el derecho administrativo-sancionatorio", Revista de Derecho (Valdivia), Vol. XXVII, No 2 (2014), pp. 147-167 (pp. 159 y ss.).
} 


\section{Polít. crim. Vol. 12, No 24 (Diciembre 2017), Art. 9, pp. 997-1043. [http://www.politicacriminal.cl/Vol_12/n_24/Vol12N24A9.pdf]}

Constitucional $^{24}$. En el derecho penal, en cambio, mantienen amplia primacía los puntos de vista - deontológicos y consecuencialistas- que solo consideran como legítima la pena "merecida" por el injusto cometido ${ }^{25}$, con relativa independencia, en el plano de la fundamentación general de la sanción, de consideraciones pragmáticas preventivas o disuasivas $^{26}$.

\subsection{Características del derecho sancionatorio administrativo chileno}

Ahora bien, ¿cuáles son las principales características del derecho sancionatorio administrativo vigente en Chile? Desde un punto de vista general y sustantivo es posible identificar cuando menos las siguientes.

\footnotetext{
${ }^{24}$ Cfr. por ejemplo CORDERO VEGA, Luis, "El decaimiento del procedimiento administrativo sancionador. Comentarios a las sentencias de la Corte Suprema del año 2010", en: VV.AA., Anuario de Derecho Público. Universidad Diego Portales, Santiago: Ediciones UDP, 2010, p. 248, con ulteriores referencias: "Existe consenso en que el derecho administrativo sancionador constituye una dimensión esencial del proceso de ejecución y aplicación de la ley, particularmente de su cumplimiento efectivo en la realidad. Las leyes y reglamentos tienen la pretensión de modificar la realidad social, encauzando la conducta privada conforme a los estándares previstos en las normas jurídicas adoptadas. Aunque resulte obvio señalarlo, las leyes y reglamentos se dictan para ser aplicados. Esta pretensión se vería completamente frustrada si la autoridad administrativa no contara con la capacidad de imponer sanciones directas a los ciudadanos (esto es, sin necesidad de recurrir a los tribunales de justicia)"; BERMÚDEZ, Jorge, "Fundamento y límites de la potestad sancionadora administrativa en materia ambiental", Revista de Derecho (Pontificia Universidad Católica de Valparaíso) XL (2013, $1^{\circ}$ Semestre), pp. 421-447; aunque el texto incidentalmente parece sugerir un enfoque punitivista, la exposición de las instituciones contempladas en la ley es elocuente en cuanto al carácter de instrumento regulatorio de la potestad sancionadora (véase esp. pp. 429 y ss.); también es el punto de partida de SOTO DELGADO, Pablo, "Sanciones administrativas", cit. nota $\mathrm{n}^{\circ} 19$, p. 190, y de VALLEJO GARRETÓN, Rodrigo, "Acerca del régimen supletorio de prescripción aplicable a las infracciones y sanciones administrativas", Revista de Derecho (Pontificia Universidad Católica de Valparaíso), XLVII (2016), pp. 281 y ss. (292 y s.), con referencias ulteriores. En el mismo sentido SILVA SÁNCHEZ, J. M., La expansión del derecho penal, Madrid: Civitas, $2^{\mathrm{a}}$ ed., 2001, p. 126, quien entiende que el derecho administrativo sancionador "es el refuerzo de la ordinaria gestión de la Administración". En la jurisprudencia del Tribunal Constitucional véase, por ejemplo, STC Rol N 2264 (2013), cons. $23^{\circ}$ y ss.

${ }^{25}$ Cfr. por ejemplo PAWLIK, Michael, Das Unrecht des Bürgers, Tübingen: Mohr Siebeck, 2012, pp. 82 y ss.; MOORE, Michael, "Justifying Retributivism", 27 Israel Law Review (1993), pp. 15-49; CAHILL, Michael T., "Retributive Justice in the Real World", 85 Washington University Law Review (2008), pp. 816870; BERMAN, Mitchell N., "Two Kinds of Retributivism", en: DUFF, R. A.; GREEN, Stuart P., Philosophical Foundations of Criminal Law, Oxford: OUP, 2011, pp. 433-457. Una visión panorámica del nuevo retribucionismo en MARTINS, Antonio, "Ein nachmetaphysisches Strafrecht? Gedanken zum retributiven Charakter der Strafe", Zeitschrift für Internationale Strafrechtsdogmatik 10/2014, pp. 514-521.

${ }^{26}$ Esta contribución no se ocupa del problema de la superposición de sanciones penales y administrativas que suele estudiarse bajo el rótulo de non bis in idem (referencias infra nota $\mathrm{n}^{\circ} 64$ )-, pero conviene aclarar desde ya que la fundamentación teleológica de la distinción entre unas y otras no prejuzga al respecto. La prohibición de superposición dice relación con la interpretación de las respectivas normas de conducta (para proscribir las superposiciones casuales o arbitrarias) y con la índole e intensidad de las sanciones (para prohibir el exceso). En este sentido razona, a mi juicio, la reciente SCA Santiago de 17.IV.2017, Rol $\mathrm{N}^{\circ}$ 1963-2015, que dejó sin efecto una multa administrativa pues ya se había impuesto una sanción penal por los mismos hechos.
} 
VAN WEEZEL, Alex "Sobre la necesidad de un cambio de paradigma en el derecho sancionatorio administrativo".

\subsubsection{Formalización de los aspectos subjetivos de la imputación}

El derecho sancionatorio de la administración formaliza los aspectos subjetivos de la imputación, sustituyendo el conocimiento de la infracción por el deber de conocer sus presupuestos. Esto puede parecer obvio en el caso de sanciones aplicadas a personas jurídicas; pero en el caso de las personas naturales ocurre sustancialmente lo mismo. Es característico que el regulador considere que el solo hecho de realizar la conducta prohibida por la ley implica necesariamente la concurrencia de todos los presupuestos de la imputación subjetiva que requiere la imposición de una sanción.

Recuérdese, a modo de ejemplo, un caso particularmente significativo por sus repercusiones en otros ámbitos ${ }^{27}$ : las resoluciones de la Superintendencia de Valores y Seguros que sancionaron a los controladores de la aerolínea LAN por infracción al deber de abstención contemplado, según el regulador, en el artículo 165 de la Ley de Mercado de Valores de la época ${ }^{28}$. Respecto de la imputación subjetiva, la Resolución Exenta $\mathrm{N}^{\circ} 307$ discurría del siguiente modo: "Hay culpa por haber ejecutado un acto prohibido por ley sabiendo o debiendo saber que le estaba prohibido, y no haber adoptado las medidas de prudencia o precaución que el legislador estimó como necesarias"29.

El tribunal que conoció de la reclamación relativa a la resolución citada fue incluso más lejos: "La conducta reprochada al señor N.N. (...) constituye, a juicio de este a quo, una clara infracción de las normas legales antes citadas [artículo 165 de la Ley de Mercado de Valores], sin necesidad de recurrir para así decidirlo, al examen de motivaciones subjetivas de culpabilidad del infractor, innecesarias del todo si se considera la patente ilicitud de su objeto al contravenir -en sí mismo- el derecho público chileno, reflexiones que al ser evidentes excluyen supuestas transgresiones a los derechos fundamentales del reclamante e inexistentes excesos administrativos de la SVS

Es importante tener en cuenta que, conforme a las defensas - pero también a la doctrina especializada-, las resoluciones sancionatorias referidas materializaron un cambio en la interpretación de la ley que, hasta ese momento, había hecho el regulador. Así, en análisis académicos posteriores se sostuvo, por ejemplo, que

\footnotetext{
${ }^{27} \mathrm{Y}$ en el cual me correspondió intervenir como parte de la defensa de uno de los sancionados.

${ }^{28}$ Las Resoluciones Exentas N ${ }^{\circ} 306$ y 307, de 6.VII.2007.

${ }^{29}$ Res. Ex. $\mathrm{N}^{\circ} 307$, de 6.VII.2007, cons. $14^{\circ}$. La SVS ha señalado que habría sostenido tal interpretación ya en sus Oficios Reservados $\mathrm{N}^{\circ} 85$ y N 86 de 5 de abril de 2005 (pero: ¿quién debe conocer el contenido de los oficios reservados de la SVS, más aun contra una praxis de signo contrario?); además invocó la SCS 27.X.2005, en causa Rol $\mathrm{N}^{\circ}$ 4930-2004, que sin embargo tiene un sentido distinto del que el regulador le atribuye. Al respecto, BASCUÑÁN, Antonio, "La regulación de la información privilegiada en el mercado de valores después de la ley 20.382", en: WILENMANN, Javier (Coord.), Gobiernos corporativos. Aspectos esenciales de las reformas a su regulación, Santiago: Legal Publishing, 2011, pp. 87-138 (nota 48). La interpretación de la SVS era tan poco plausible que luego se modificó la ley para sancionarla (Ley $\mathrm{N}^{\circ} 20.382$ ).

${ }^{30}$ Sentencia del $27^{\circ}$ Juzgado Civil de Santiago, de 8.I.2009, en causa Rol C-14627-2007, cons. $10^{\circ}$ (cursivas añadidas).
} 


\title{
Polít. crim. Vol. 12, No 24 (Diciembre 2017), Art. 9, pp. 997-1043. [http://www.politicacriminal.cl/Vol_12/n_24/Vol12N24A9.pdf]
}

\begin{abstract}
"se trata de un caso emblemático por varias razones: era la primera vez que la SVS aplicaba una multa por deber de abstención. Luego de esta sanción la SVS dictó en el año 2008 una norma que exige a las empresas, a través de la autorregulación, elaborar sus propias normativas respecto al uso de información privilegiada. En ellas normalmente se reconoce que los directores no pueden comprar acciones en los períodos previos y posteriores al conocimiento de los estados financieros de la empresa". ${ }^{31}$
\end{abstract}

La introducción del denominado "deber de abstención" exigió, incluso, la aprobación de una modificación legislativa en 2009, dos años después de las sanciones, a través de la Ley $\mathrm{N}^{\circ} 20.382$.

Lo anterior no significa que el derecho administrativo imponga sanciones sobre la base de lo que se suele denominar como "responsabilidad objetiva" 32 , desestimando las defensas de caso fortuito y fuerza mayor. La prescindencia de los aspectos subjetivos de la imputación se manifiesta más bien en el rechazo en sede administrativa de alegaciones basadas en lo que en derecho penal se denomina genéricamente "errores inevitables". El reconocimiento de la excusa por error inevitable en términos amplios -esto es, incluyendo el error sobre aspectos valorativos- es una conquista relativamente reciente del derecho penal, que se justifica por el modo en que este sistema sancionatorio cumple su función ${ }^{33}$. La existencia de la excusa refuerza además la intensidad del reproche que se dirige, como contrapartida, a quien es condenado por un delito; la condena expresa así un fracaso integral de la persona como ciudadano.

Como el derecho administrativo está interesado en dotar de eficacia a una regulación mediante el reforzamiento futuro de ciertos estándares y no en una contradicción de la negación del derecho, su reacción sancionatoria no toma en cuenta una eventual desorientación del individuo, sino la posibilidad objetiva de orientación para un sujeto medio que se desenvuelve en el ámbito regulado de que se trata. Un razonamiento de este tipo se observa con cierta frecuencia en los fallos del Tribunal Constitucional que desestiman requerimientos de inaplicabilidad por déficit de determinación de la conducta prohibida, cuando los estándares de conducta forman parte de la reglamentación infralegal de mercados o actividades reguladas.

Así, por ejemplo, en el Rol 2154 (2012), sentenció que “el conocimiento de los reglamentos o normas que regulan las actividades de la construcción es esperable, dado que la parte requirente desempeña justamente dicha actividad. Ante dicha situación, constituye una

${ }^{31}$ VÁSQUEZ, M. Fernanda, "Caso LAN y uso de información privilegiada: un análisis de la correcta delimitación de las infracciones legales”, Revista Ius et Praxis, Año 16, № 2 (2010), pp. 461-484 (nota 4).

${ }^{32}$ Una útil sistematización de las defensas que puede esgrimir el presunto infractor conforme a la jurisprudencia administrativa puede verse en OSORIO, Cristóbal, Manual de procedimiento administrativo sancionador. Parte General, Santiago: Thomson Reuters, 2016, pp. 320 y ss.: errónea formulación de cargos, caso fortuito, estado de necesidad, cumplimiento de un deber o ejercicio legítimo de un derecho o cargo, confianza legítima.

${ }^{33}$ Cfr. WALTER, Tonio, Der Kern des Strafrechts. Die allgemeine Lehre vom Verbrechen und die Lehre vom Irrtum, Tübingen: Mohr Siebeck, 2006, pp. 217 y ss.; también VAN WEEZEL, Alex, Error y mero desconocimiento en derecho penal, Santiago: Legal Publishing, 2008, passim. 
VAN WEEZEL, Alex "Sobre la necesidad de un cambio de paradigma en el derecho sancionatorio administrativo".

objeción constitucionalmente inadmisible aducir que los sujetos no han podido conocer las reglas que rigen los ámbitos específicos de actividad en los que se desempeñan profesionalmente"34. Del mismo modo se argumentó en el Rol 2264 (2013): "Que, finalmente, la empresa sostuvo en estrados que la falta de tipicidad es tan clara, que no supo que había infringido la normativa hasta que la Superintendencia dictó la resolución 1370/2011". Sin embargo, "si bien para esta Magistratura, no experta en la materia, estas normas pueden ser de difícil comprensión, no puede pasar lo mismo con empresas que operan en el sector eléctrico (...) [L]os deberes vinculados a los aportes financieros reembolsables no son referencias indeterminadas o desconocidas, sino familiares para las empresas que operan en el sector de la distribución",35.

De este modo se sustituye el conocimiento por un deber de conocer y se despacha un análisis de evitabilidad que un tribunal penal estaría obligado a realizar de un modo pormenorizado.

\subsubsection{Prescindencia de la tipicidad como determinación de la norma de conducta}

El derecho sancionatorio administrativo opera en términos generales al margen de lo que en derecho penal se conoce como tipicidad o determinación de los ilícitos. Así, por ejemplo, en el derecho sancionatorio administrativo es usual que la habilitación para castigar adopte la fórmula general que reza: "Las infracciones a esta ley que no tengan asignada una sanción especial serán castigadas con multa de tanto a tanto". El artículo 174 del Código Sanitario establece $v$. gr. que "la infracción de cualquiera de las disposiciones de este Código o de sus reglamentos y de las resoluciones que dicten los Directores de los Servicios de Salud o el Director del Instituto de Salud Pública de Chile, según sea el caso, salvo las disposiciones que tengan una sanción especial, será castigada con multa de un décimo de unidad tributaria mensual hasta mil unidades tributarias mensuales. Las reincidencias podrán ser sancionadas hasta con el doble de la multa original". Los artículos 36 y 37 de la Ley $\mathrm{N}^{\circ}$ 21.000, que sustituyó la ley orgánica de la SVS (Decreto Ley $\mathrm{N}^{\circ}$ 3.538), van incluso más allá, pues disponen -conservando la fórmula del texto derogado-, que quienes "incurrieren en infracciones a las leyes, reglamentos, estatutos y demás normas que las rijan, o en incumplimiento de las instrucciones y órdenes que les imparta la Comisión, podrán ser objeto de la aplicación por esta (...) de una o más de las siguientes sanciones".

Como se puede apreciar, la ley faculta a la administración para imponer multas por “cualquier" infracción a la ley. Además, como ocurre con la regla del Código Sanitario, la faculta para sancionar el incumplimiento de normas reglamentarias o de resoluciones de

\footnotetext{
34 STC Rol N² 2154 (2012), cons. 49. La sentencia contiene, eso sí, dos prevenciones que rechazan expresamente el argumento basado en el deber de conocer. Allí se señala que los jueces firmantes "son del parecer de que la garantía normativa del artículo $19 \mathrm{~N}^{\circ} 3^{\circ}$, inciso final, de la Carta Fundamental, más que decir relación con el conocimiento o comprensión que de la ley pueda tener un encartado, consagra una garantía destinada a proteger a las personas del ejercicio despótico del poder punitivo del Estado". Con ello se apartan de la tesis de la certeza subjetiva como fundamento del mandato de determinación, para volver explícitamente a la fundamentación garantista o limitativa del poder punitivo del Estado.

${ }^{35}$ STC Rol N 2264 (2013), cons. 39.
} 
Polít. crim. Vol. 12, No 24 (Diciembre 2017), Art. 9, pp. 997-1043.

[http://www.politicacriminal.cl/Vol_12/n_24/Vol12N24A9.pdf]

todo tipo dictadas por la misma administración. El jefe de servicio goza de una potestad sancionatoria general respecto de los particulares que desobedezcan las resoluciones que dicte, cualesquiera que estas sean. Aparte de esta vaga asociación con un comportamiento desobediente que el precepto inspira, en el tipo nada hay que se asemeje a una descripción de "la conducta que se sanciona", como exige la Constitución en materia penal. Por si fuera poco, las reglas de los artículos 36 y 37 de la Ley $N^{\circ} 21.000$ permiten además la imposición de sanciones por incumplimiento de meras instrucciones $\mathrm{u}$ órdenes específicas del regulador.

La consecuencia de todo ello es que las atribuciones sancionatorias en sede administrativa cubren un ámbito incomparablemente más amplio que el fragmentario y excepcional campo de los ilícitos penales. En efecto, si no hace falta precisar en una ley el presupuesto básico de aplicación de la sanción administrativa -la conducta que se sanciona-, entonces el ámbito de su potencial de aplicación se extiende a toda la regulación sectorial ${ }^{36}$. Esto no implica necesariamente que la sanción sea siempre procedente o que pueda imponerse sin resguardos o garantías de ninguna clase. Pero ciertamente dentro de esos resguardos no se encuentra algo parecido a lo que en el derecho constitucional penal se conoce como principio de tipicidad.

Para bien o para mal, la misma jurisprudencia que proclama la supuesta identidad sustancial entre el derecho sancionatorio administrativo y el derecho penal ha ratificado en repetidas ocasiones la legitimidad de esta indeterminación de las infracciones. He tenido oportunidad de referirme a la jurisprudencia del Tribunal Constitucional en otro lugar, destacando una tendencia subjetivista que no ha hecho sino acentuarse en los últimos años. Allí también se da cuenta de cómo el Tribunal Constitucional, al menos desde el Rol 480 (2006), ha legitimado el establecimiento de infracciones administrativas mediante fórmulas genéricas. A juicio del tribunal, lo que el legislador debe describir para habilitar la regulación reglamentaria de índole sancionatoria no es la conducta amenazada con una sanción, sino simplemente el deber $\mathrm{u}$ obligación del administrado cuyo incumplimiento puede ser sancionado por la administración. Resulta fácil advertir que esto nada tiene que ver con la descripción de la conducta a la cual se refiere el inciso final del artículo $19 \mathrm{~N}^{\circ} 3$ de la Constitución $^{37}$.

La jurisprudencia ha validado también expresamente la definición de infracciones que se constituyen por la mera desobediencia ante órdenes o instrucciones particulares del regulador sectorial. El ya mencionado Rol 2264 (2013) contiene la sentencia más relevante al respecto. Aislando dentro de lo posible las dimensiones jurídicas pertinentes del conflicto -no se puede olvidar que estas sentencias inciden en causas caracterizadas por situaciones de hecho singulares, las que en este caso llevaron incluso a que tres ministros estuvieran

\footnotetext{
${ }^{36}$ Todo ello sin considerar siquiera las complejidades de la indispensable cooperación público-privada; al respecto RAJEVIC, Enrique, "La sinuosa reserva legal de la potestad sancionatoria y los privados que ejercen funciones públicas: Navegando entre las relaciones de sujeción especial y la contractualización”, en: ARANCIBIA/ALARCÓN, Sanciones Administrativas, cit. nota n ${ }^{\circ} 19$, pp. 89 y ss.

${ }^{37}$ Cfr. VAN WEEZEL, Alex, La garantía de tipicidad en la jurisprudencia del Tribunal Constitucional, Santiago: Abeledo Perrot, 2011, pp. 159 y ss.; sobre la evolución posterior, ÉL MISMO, "Mandato de determinación de los tipos penales: una garantía en peligro", Revista Penal México N 5 (2013), pp. 207-216.
} 
VAN WEEZEL, Alex "Sobre la necesidad de un cambio de paradigma en el derecho sancionatorio administrativo".

por condenar en costas a la requirente-, se observa que para el tribunal reglas como la del citado artículo 27 de la ley orgánica de la SVS cumplen perfectamente bien con el principio de legalidad de la sanción administrativa. En efecto,

"las órdenes dadas por la Superintendencia ejecutan un mandato legal, que es imposible que pueda tener mayores niveles de precisión o densidad, dada la complejidad, dinamicidad [sic] y aspectos técnicos involucrados en estos asuntos. De ahí que la ley convoque a la complementación de la administración, facultándola para impartir órdenes que concreten deberes legales". ${ }^{38}$

Pero además se cumple a juicio del tribunal con la determinación que cabe exigir en el ámbito infraccional. La definición de infracciones por la mera desobediencia ante órdenes o instrucciones particulares del regulador obedece a que

“el legislador no puede ir más allá, porque no puede prever la infinidad de incumplimientos en que puede incurrir una determinada empresa. Para ilustrar lo anterior, baste considerar que la Ley de Servicios Eléctricos tiene 225 artículos y el Reglamento de esta ley (D.S. N N $^{\circ}$ 327/98, Ministerio de Minería) tiene 327 artículos. La mayoría de estas disposiciones establecen deberes para las empresas, que eventualmente pueden ser transgredidos. La única forma que encontró el legislador de englobar todos estos deberes, es sancionando la infracción de normas y el incumplimiento de instrucciones y órdenes". 39

La jurisprudencia de la Corte Suprema es, si cabe, aun más drástica al respecto. Aparte de los fallos citados previamente en la sección 1, es notable la sentencia de casación que afirmó la suficiencia del artículo 67 del Código Sanitario como único fundamento típico para la imposición de sanciones administrativas ${ }^{40}$. Nótese que el precepto en cuestión se limita a establecer lo siguiente: "Corresponde al Servicio Nacional de Salud velar por que se eliminen o controlen todos los factores, elementos o agentes del medio ambiente que afecten la salud, la seguridad y el bienestar de los habitantes en conformidad a las disposiciones del presente Código y sus reglamentos".

Este último ejemplo muestra muy claramente que la potestad sancionatoria de la administración en el ordenamiento chileno es una herramienta al servicio del buen funcionamiento de un determinado ámbito de regulación. Por eso la Corte Suprema no tiene inconvenientes en derivar inmediatamente facultades sancionatorias de una norma general sobre la competencia de un servicio para mantener el buen funcionamiento de un sector. Según el Supremo Tribunal, de la facultad para "velar por que se eliminen o controlen todos los factores, elementos o agentes del medio ambiente que afecten la salud, la seguridad y el bienestar de los habitantes" se sigue sin más la potestad para sancionar al que se comporta en contradicción con estos fines. Ni siquiera hace falta precisar cuáles son los

\footnotetext{
${ }^{38}$ STC Rol N 2264 (2013), cons. 30.

${ }^{39}$ STC Rol N 2264 (2013), cons. 38०.

40 SCS 16.IX.2013, Rol N $7397-2012$, con comentario crítico (“sentencia manipulativa de la ley") de SOTO DELGADO, Pablo, "Un mal caso para flexibilizar la tipicidad en el derecho administrativo sancionador", Revista Chilena de Derecho, Vol. 42, N² (2015), pp. 701 y ss.
} 
Polít. crim. Vol. 12, No 24 (Diciembre 2017), Art. 9, pp. 997-1043.

[http://www.politicacriminal.cl/Vol_12/n_24/Vol12N24A9.pdf]

deberes que concretamente pesan sobre los administrados y cuya infracción puede dar lugar a la imposición de sanciones.

El citado fallo contiene además un párrafo que puede resultar tan ilustrativo como inquietante, pues pone exactamente de cabeza la idea de tipicidad: "No se trata ya tanto de un esfuerzo por comprobar si en la realidad enjuiciada se cuenta con los elementos del precepto castigador -deducción- sino, más propiamente, de hurgar en el espectro normativo cuál sea el modo que se advierte mayormente legítimo para sancionar una conducta claramente prohibida -inducción-" ${ }^{, 41}$.

\subsubsection{Principio de oportunidad o selectividad en la persecución}

En el ámbito del derecho administrativo sancionatorio rige el principio de oportunidad en la persecución y no el principio de legalidad -persecución obligatoria- propio del derecho penal. Como la sanción tiene por objeto dotar de eficacia a una determinada regulación, mantener el buen funcionamiento de un sector, es lógico que sea el jefe del servicio fiscalizador y sancionador el que resuelva si, en cada caso concreto, resulta conveniente instruir un procedimiento sancionatorio. El regulador se relaciona de muchos modos con el regulado, y muchas veces existen cauces más eficaces que la sanción para obtener los objetivos señalados.

La consecuencia necesaria de esta discrecionalidad es que las decisiones de persecución no quedan, precisamente, sujetas a un control de legalidad, sino solo y en principio a un control vía desviación de poder. Esta forma de control es muy restrictiva y solo está disponible para casos patentes de abuso ${ }^{42}$. Mientras la autoridad administrativa utilice adecuadamente su discrecionalidad, no hay mayores problemas, pero ¿qué ocurre cuando se introducen criterios de persecución sistemáticamente selectivos en perjuicio de ciertos actores en un determinado sector? Hay que recordar que en Chile una parte muy significativa de los cargos de la administración pública dependen, directa o indirectamente, del gobierno de turno. Incluso aunque haya buenas razones para descartar por regla general una persecución política o ideológica, nada impide que los funcionarios actúen de buena fe con un cierto sesgo. Ello es tolerable cuando se trata de la implementación de una política pública, pero ¿lo es también cuando se trata de la imposición de sanciones que, además, no consisten en exigencias de mejoramiento del estándar de conducta, sino simplemente en el pago de una suma a beneficio fiscal?

En el ámbito penal rige, en cambio, el principio de legalidad ${ }^{43}$. Con todas las dificultades prácticas que significa y conlleva su aplicación, es derecho vigente que, al tomar

${ }^{41}$ SCS 16.IX.2013, Rol No 7397-2012, cons. 14 ${ }^{\circ}$.

${ }^{42}$ Un diagnóstico del problema y algunas vías de solución plantea HUEPE, Fabián, "El problema de la discrecionalidad en la potestad sancionadora de la Administración. Su control a través del principio de razonabilidad", en: ARANCIBIA/ALARCÓN, Sanciones Administrativas, cit. nota n ${ }^{\circ} 19$, pp.167 y ss.; los artículos $2^{\circ}, 3^{\circ}$ y 53 de la Ley $\mathrm{N}^{\circ} 18.575$ son, sin embargo, extraordinariamente generales para configurar un test fuerte de razonabilidad.

${ }^{43}$ Con escasas y discutidas excepciones, como ocurre en el caso de los delitos de acción privada o de acción pública previa instancia particular (artículos 54 y 55 del Código Procesal Penal) y en los delitos que tienen 
VAN WEEZEL, Alex "Sobre la necesidad de un cambio de paradigma en el derecho sancionatorio administrativo".

conocimiento de la existencia de un hecho que reviste caracteres de delito, los órganos de persecución penal deben iniciar una investigación y promover la persecución penal, y que no la pueden suspender, interrumpir o hacer cesar su curso salvo en los casos previstos en la ley (artículo 166 del Código Procesal Penal). Algunos de estos casos admiten un cierto margen de apreciación, pero ella está sujeta a un control jurisdiccional de legalidad y, en ciertas hipótesis, también de mérito, como ocurre por ejemplo a propósito de las solicitudes de reapertura de la investigación (artículo 257 del Código Procesal Penal).

\subsubsection{Economía institucional}

El sistema sancionatorio administrativo se caracteriza por su extraordinaria economía. Mientras la realización práctica de las garantías penales tiene un costo altísimo para el Estado - hay al menos tres instituciones completas, cada una con millares de funcionarios y empleados, dedicadas a hacer efectivas tales garantías-, el costo del aparato sancionatorio administrativo es mucho menor. Un team de algunos funcionarios del área de cumplimiento de un servicio público es suficiente para instruir el procedimiento e imponer, con la venia del jefe de ese servicio, las sanciones correspondientes.

Por ejemplo, hace poco más de dos años el Tribunal Constitucional se pronunció en causa de inaplicabilidad respecto de la clausura que los inspectores del trabajo están facultados para imponer cuando el infractor que reincide en cierto tipo de contravenciones ${ }^{44}$. La sentencia da cuenta de un empate de votos, pero lo interesante es que para la imposición de la clausura en caso de reincidencia prácticamente no existe un procedimiento en la ley. Solo una vez impuesta la sanción procede el reclamo, con suspensión meramente facultativa de la medida. Ello se encuentra en sintonía con la doctrina de la ejecutoriedad de los actos administrativos -también de los sancionatorios-contenida en el fallo de la Corte Suprema comentado en la sección anterior. El ordenamiento contempla muchas situaciones $\operatorname{análogas}^{45}$.

Si la imposición de la sanción administrativa es relativamente barata para el Estado, son en cambio enormes los beneficios económicos que obtiene mediante el cobro de las multas, especialmente si se tiene en cuenta el incremento exponencial de su cuantía en los últimos años. Así, por ejemplo, la Ley Orgánica de la SVS autoriza al regulador a imponer una multa equivalente al 30\% de la "operación irregular". En el denominado caso Cascadas, la SVS impuso a uno de los sancionados una multa de 550.000 Unidades de Fomento. Con independencia de si la multa resultaba o no procedente y proporcional -finalmente el Tribunal Constitucional la consideró desproporcionada en el Rol 2922 (2016), según se vio-, este dinero no está destinado a reparar a quienes resultaron perjudicados por las infracciones, sino que va directa y definitivamente a las arcas fiscales. El Código

una decisión administrativa como presupuesto de procesabilidad (por ejemplo, la totalidad de los delitos fiscales conforme al artículo 162 del Código Tributario).

${ }^{4}$ STC Rol N 2346 (2014). Uno de los preceptos impugnados era el artículo 34 del DFL N² 2 (1967) del Ministerio del Trabajo y Previsión Social, que establece esta potestad de clausura de establecimiento o faena en caso de reincidencia.

${ }^{45}$ Más ejemplos en LARA, J. L., "Procedimientos de fiscalización/sanción y Ley N 19.880: ¿Suficiencia de la supletoriedad", en: ARANCIBIA/ALARCÓN, Sanciones Administrativas, cit. nota n 19, pp. 284 y ss. 
Polít. crim. Vol. 12, No 24 (Diciembre 2017), Art. 9, pp. 997-1043.

[http://www.politicacriminal.cl/Vol_12/n_24/Vol12N24A9.pdf]

Tributario, solo para citar otro ejemplo, permite sancionar con multas equivalentes al $300 \%$ del tributo eludido. El desiderátum del artículo 501 del Código Penal ha sido abandonado y con razón- hace mucho tiempo por el legislador.

En este contexto vale la pena recordar también el estado de la cuestión en materia de solve et repete -característico del procedimiento de reclamación frente a sanciones administrativas- en la jurisprudencia del Tribunal Constitucional. Conforme a ella, la constitucionalidad de esta institución debe determinarse caso a caso, mediante una ponderación de la medida en que la exigencia de pago de la multa o una parte de ella afecta el ejercicio del derecho al recurso ${ }^{46}$. En materia penal, en cambio, resultaría impensable que alguien tenga que comenzar a cumplir la condena como requisito para poder impugnar la sentencia condenatoria ${ }^{47}$.

\section{Un camino equivocado}

Las características anteriores, apenas esbozadas, no son superables o extirpables. Ellas son en gran medida consustanciales al derecho sancionatorio administrativo y, por lo mismo, en la mayoría de los casos es poco lo que se ha de corregir. Los inspectores del trabajo deben poder suspender de inmediato la operación de una empresa de transportes que, en forma reincidente, no da suficientes garantías de seguridad para los conductores y las demás personas participantes en el tráfico motorizado. La autoridad sanitaria debe estar facultada para tomar medidas urgentes -suspensivas o privativas de derechos- cuando el que explota un restaurante vulnera, aunque sea solo prima facie, las normas de higiene y seguridad que la misma autoridad ha dictado, también con referencia a la particular situación de la persona sancionada. Algo análogo vale para los fiscalizadores del buen uso de las subvenciones escolares. Probablemente no sea "imposible" - como ha declarado la Corte Suprema-someter el derecho sancionatorio administrativo a un estándar de previsibilidad de las sanciones superior al actual, pero aun así parece destinado al fracaso cualquier intento de imponerle un genuino -y no solo programático- estándar de tipicidad. Ello es aplicable a todos los "principios penales".

Por lo mismo, sería un error pretender "redimir" al derecho sancionatorio administrativo de los supuestos déficits que le aquejarían si se le compara con el derecho penal, endosándole de un modo siempre matizado y relativo $-\mathrm{y}$, por lo mismo, tendencialmente nominal- los principios penales. Este camino presenta todas las desventajas imaginables: priva al derecho sancionatorio administrativo de su eficacia, o al menos la daña severamente; produce la falsa apariencia de un derecho sancionatorio plenamente observante de las garantías penales; se fomenta una expansión descontrolada del derecho sancionatorio administrativo, bajo el pretexto -más pensado que expresado- de que es análogamente

\footnotetext{
${ }^{46}$ Últimamente, recogiendo la doctrina del tribunal en fallos anteriores, STC Rol $N^{\circ} 2475$ (2014). Crítico sobre la regla en general y su configuración en el derecho chileno, LEWIS, Sebastián, "El solve et repete. Estudio de una regla que debe ser derogada", en: ARANCIBIA, Jaime; MARTÍNEZ, José I.; ROMERO, Alejandro (Coords.), Litigación pública, Santiago: Thomson Reuters, 2011, pp. 467-502.

${ }^{47}$ En la medida en que se aproximan a esta lógica son cuestionables los incisos $2^{\circ}$ y $3^{\circ}$ del artículo 149 del Código Procesal Penal. Pero se trata justamente de la regulación de la prisión preventiva, que obedece a la lógica de prevención de peligros propia del derecho administrativo.
} 
VAN WEEZEL, Alex "Sobre la necesidad de un cambio de paradigma en el derecho sancionatorio administrativo".

garantista y, por lo tanto, no constituye una amenaza para los derechos fundamentales, y se promueve, por las mismas razones, la imposición administrativa de sanciones cuasi-penales por su magnitud y naturaleza.

Los efectos anteriores ya se han producido en el ordenamiento jurídico chileno y, a juzgar por el estado actual de la discusión, todo indica que seguirán intensificándose. El afán por equiparar en lo sustancial el derecho penal y el derecho sancionatorio administrativo ha conducido a un dilema que debe ser observado y considerado en toda su importancia. En efecto, al amparo de la equiparación sustancial, el derecho sancionatorio administrativo ha crecido y se ha desarrollado como un "pequeño derecho penal" caracterizado por la imposición de cuantiosísimas multas e inhabilidades, principalmente a las personas jurídicas -es decir, a las personas naturales dueñas del capital-, pero también en forma directa a las personas naturales. Los sectores o ámbitos de regulación son tan variados como las actividades económicas de alguna significación, de modo que puede hablarse sin exageración de una omnipresencia de la potestad sancionatoria de la administración.

Esta omnipresencia viene acompañada de esfuerzos del legislador, la Contraloría General de la República y los tribunales de justicia -especialmente, del Tribunal Constitucional-en orden a imponer y desarrollar una serie de estándares y restricciones para el ejercicio de la potestad sancionatoria $^{48}$. Una sentencia relativamente reciente del Tribunal Constitucional lo sintetiza en los siguientes términos:

"La jurisprudencia de esta Magistratura ha puntualizado que las sanciones administrativas deben cumplir dos tipos de garantías. Por una parte, aludiendo a las garantías sustantivas, ha señalado que los principios inspiradores del orden penal deben aplicarse, por regla general y con matices, al derecho sancionatorio administrativo, puesto que ambos son manifestaciones del ius puniendi propio del Estado. Por otra, que deben cumplir con las garantías vinculadas al debido procedimiento, permitiendo a quienes puedan ser alcanzados por dichos castigos defenderse de los cargos que les dirija la autoridad, rendir pruebas e impugnar la sanción una vez aplicada". ${ }^{49}$

En materias adjetivas se trata, como el mismo tribunal reconoce, de un estándar básico y mínimo de debido proceso. Por cierto que tal estándar se encuentra distante de las

\footnotetext{
${ }^{48}$ Sobre ellos véase ampliamente CORDERO QUINZACARA, Eduardo, "Los principios que rigen la potestad sancionadora de la Administración en el derecho chileno", Revista de Derecho (Pontificia Universidad Católica de Valparaíso) XLII (2014, $1^{\circ}$ Semestre), pp. 399-439; ÉL MISMO, Derecho Administrativo Sancionador, Santiago: Thomson Reuters, 2014, pp. 213 y ss.

${ }^{49}$ STC Rol N 2682 (2014), cons. 11 ${ }^{\circ}$, que remite a la jurisprudencia citada en STC Rol No 2264 (2013), cons. $33^{\circ}$. Y agrega a continuación: "[U]n debido procedimiento tiene lugar cuando se actúa en la forma que prescriben aquellas normas y principios procesales que resultan fundamentales para el resguardo efectivo del derecho a defensa. A la imposición de sanciones administrativas, pues, necesariamente debe anteceder una serie concatenada de trámites, tan esenciales como un acta o acusación o formulación de cargos precisa y sostenida en una investigación previa, su comunicación al presunto infractor y la oportunidad para que éste pueda plantear defensas o alegaciones y rendir pruebas. Todo ello terminado, si procede, con una sanción fundada y solo por hechos que han sido objeto de cargos, susceptible de ser impugnada ante un tribunal" (STC Rol N 2682 [2014], cons. $12^{\circ}$ ).
} 
Polít. crim. Vol. 12, No 24 (Diciembre 2017), Art. 9, pp. 997-1043.

[http://www.politicacriminal.cl/Vol_12/n_24/Vol12N24A9.pdf]

instituciones del proceso penal, algunas de las cuales han sido discutidas ante la misma Magistratura Constitucional: el debate en torno al acceso de la víctima a la jurisdicción cuando el fiscal no procede a formalizar la investigación, la legitimidad de la prueba obtenida en el contexto de la recopilación de antecedentes contemplada en el Código Tributario, la discusión sobre la ausencia de recursos contra el auto de apertura del juicio oral cuando en éste se excluye prueba de la defensa, la controversia sobre la obligación de declarar bajo juramento en causas civiles cuando el absolvente puede ser enjuiciado por los mismos hechos en sede penal, las situaciones en las cuales el juez de garantía debe decretar la separación de acusaciones para asegurar el derecho a defensa, y muchos otros.

El camino equivocado consistiría, a mi juicio, en tratar de instalar por vía legislativa o jurisprudencial un proceso penal en miniatura para la imposición de sanciones administrativas. El derecho sancionatorio administrativo no resiste estas discusiones como las enumeradas en su operatoria cotidiana, pues lo convertirían en una herramienta inútil. El legislador debe cumplir el mandato constitucional de garantizar un procedimiento racional y justo de un modo que sea compatible con la finalidad de la sanción administrativa. Este procedimiento debe existir y además debe ser acorde con el carácter aflictivo de este instrumento de enforcement, pero esto no significa que deba asimilarse al proceso penal. Por otro lado, si en el corto plazo los esfuerzos institucionales para asimilar los estándares son un paliativo para el justiciable singular $-\mathrm{y}$, en el estado actual de la legislación, también una exigencia de justicia, según se verá-, en el mediano y largo plazo terminarán por ahogarlo.

Esfuerzos de esta especie ha venido haciendo en los últimos años el propio legislador. Los artículos 46 bis a 53 de la Ley $\mathrm{N}^{\circ} 19.995$ sobre Casinos de Juego, por ejemplo, tipifican con bastante detalle una serie de contravenciones, entre las que se cuentan la obstaculización de la fiscalización, la admisión de menores y la manipulación de implementos de los juegos. Además, en el artículo 55 se reguló un procedimiento sancionatorio especial. Sin embargo, el artículo 46 mantiene la cláusula general clásica del derecho sancionatorio administrativo: "Las infracciones a esta ley que no tengan señalada una sanción especial serán penadas con multa a beneficio fiscal de tres a noventa unidades tributarias mensuales. En caso de reincidencia, dentro de un período no superior a un año, estas multas se duplicarán”. Es decir, por alguna razón el legislador consideró necesario tipificar ciertas infracciones, ni siquiera las más graves, dejando otras a la apreciación del regulador.

La Ley $\mathrm{N}^{\circ} 20.529$ sobre Sistema de Aseguramiento de la Calidad de la Educación, por su parte, reguló en su artículo 66 y siguientes un detallado procedimiento para la imposición de sanciones, que contempla incluso la designación de un "fiscal instructor" para cada caso particular, "encargado de su tramitación, de formular cargos, de investigar los hechos, solicitar informes, ponderar las pruebas y disponer toda otra diligencia que dé curso al procedimiento". Sobre la base de su informe, corresponde al Director Regional de la Superintendencia de Educación la imposición de las sanciones. La ley clasifica también las sanciones en graves, menos graves y leves, y establece sanciones diversas para cada grupo, con rangos mínimos y máximos para la sanción de multa. Sin embargo, en la definición de 
VAN WEEZEL, Alex "Sobre la necesidad de un cambio de paradigma en el derecho sancionatorio administrativo".

las diversas infracciones -que el legislador se esfuerza por realizar- figura también la cláusula general: "Infringir los deberes y derechos establecidos en la normativa educacional que no sean calificados como infracción grave" $"$.

Particularmente interesante resulta también la discusión que tiene lugar actualmente en el Congreso a raíz del proyecto de ley para modificar la Ley $\mathrm{N}^{\circ} 19.496$, sobre protección de los derechos de los consumidores (Boletín $\mathrm{N}^{\circ}$ 9369-03). El proyecto pretende, entre otros muchos aspectos, ampliar el ámbito de aplicación del derecho sancionatorio administrativo, otorgando facultades sancionatorias al Servicio Nacional del Consumidor. La propuesta contiene un procedimiento elemental, pero acorde con los parámetros reconocidos por la justicia constitucional. Las indicaciones más recientes, además, plantean una abundantísima reglamentación de los criterios para la determinación de las sanciones de multa. Las infracciones, sin embargo, salvo contadas excepciones, siguen consistiendo en la vulneración de cualquiera de los preceptos de la Ley $\mathrm{N}^{\circ} 19.496$.

La Ley $\mathrm{N}^{\circ}$ 21.000, publicada el 23 de febrero de 2017, que creó la Comisión de Mercado Financiero, constituye sin duda un caso especial. Las reglas destinadas al procedimiento sancionatorio y la investigación previa ocupan en conjunto más de un tercio de todo el cuerpo legal, por lo que puede decirse que la Comisión es una entidad diseñada para aplicar sanciones administrativas y para preparar la imposición de sanciones penales.

En efecto, la continuidad que se pretende establecer entre el procedimiento sancionatorio administrativo y el proceso penal es absoluta. Por eso, la ley regula los efectos de la delación compensada y establece expresamente que se entenderá que las medidas intrusivas autorizadas conforme a su normativa cumplen con la autorización judicial requerida para servir como prueba en un futuro proceso penal ${ }^{51}$. Esta instrumentalización del procedimiento administrativo para la obtención de prueba que luego será utilizada en un proceso penal es perturbadora por diversas razones. Ante todo, contradice la idea de que la sanción administrativa y la sanción penal responden a lógicas diferentes. Así como el recurso a los principios penales no debería desnaturalizar la potestad administrativa sancionatoria -desconociéndose la intención y fines que el legislador tuvo en consideración al optar por sancionar un ilícito conforme al derecho administrativo ${ }^{52}$, , el ejercicio de tal potestad no puede convertirse en un mecanismo para debilitar las garantías propias del proceso penal, desnaturalizándolo.

\footnotetext{
${ }^{50}$ En ciertos casos se contempla como medida precautoria la retención inmediata, total o parcial, del pago de la subvención, que debe ordenarse "mediante resolución fundada", "previa audiencia" del afectado, y ha de ser "proporcional" al daño causado. La medida solo puede durar hasta quince días corridos, pero nada impide decretarla nuevamente si se mantienen las circunstancias que le dieron origen. Existe posibilidad de impugnación dentro de los diez días hábiles siguientes. Está por verse si la regulación de la medida precautoria resultará compatible con su eficacia.

${ }^{51} \mathrm{Si}$ se tiene en cuenta la desmesurada amplitud con que se han interpretado hasta ahora las figuras delictivas que contempla la Ley $\mathrm{N}^{\circ} 18.045$, es posible que se avecinen tiempos complejos para el respeto a las garantías individuales.

${ }^{52}$ SCS 30.X.2014, Rol 1.079-2014, cons. $9^{\circ}$.
} 
Polít. crim. Vol. 12, No 24 (Diciembre 2017), Art. 9, pp. 997-1043.

[http://www.politicacriminal.cl/Vol_12/n_24/Vol12N24A9.pdf]

Este es el núcleo de la oposición que expresó en su momento el pleno de la Corte Suprema contra las facultades que se confiere a la Comisión para requerir el alzamiento del secreto bancario previa autorización judicial, para allanar, descerrajar, interceptar toda clase de comunicaciones y ordenar a otros organismos públicos la entrega de antecedentes, aunque estén sujetos a secreto o reserva, todo ello cuando esté investigando infracciones que se encuentren también tipificadas como delito. En palabras del Supremo Tribunal:

"Es necesario preguntarse sobre la necesidad, justificación, validez y nuevamente, la constitucionalidad de otorgar a un órgano de la administración del Estado -que se relacionará con el Gobierno a través del Ministerio de Hacienda- que investiga sanciones administrativas, la facultad de realizar investigaciones de este tipo con tan intensas posibilidades de perturbar garantías constitucionales y derechos, con una regulación que parece inadecuada para efectos de su autorización, sobre todo en consideración a que la finalidad se refiere a acreditar infracciones que serían al mismo tiempo penales". 53

Esta preocupación se encuentra justificada, pues la Constitución establece claramente que solo corresponde al Ministerio Público la investigación de los delitos, y el Código Procesal Penal -haciendo operativas las garantías del debido proceso y la presunción de inocenciacontiene una detallada regulación sobre la procedencia y ejecución de las medidas intrusivas, que en la Ley $\mathrm{N}^{\circ} 21.000$ brilla por su ausencia. Se establece así, agrega el informe, "una suerte de sistema de investigación administrativa, centrado en la ciudad de Santiago para la autorización de las medidas intrusivas, mediante un procedimiento que no está a la altura y estándar de la regulación de la investigación imparcial y objetiva de delitos penales" $"$.

Sin perjuicio de estas aprehensiones, la nueva normativa también da cuenta de un esfuerzo por configurar un procedimiento sancionatorio racional y justo, que comienza por entregar las decisiones sancionatorias a un órgano colegiado, cuyos integrantes -con excepción del presidente y jefe del servicio- son designados por el ejecutivo con acuerdo del Senado. Sin embargo, aunque la ley clarifica algunos asuntos procesales que daban lugar a incertidumbre, su regulación sigue siendo elemental. Ya se vio que los artículos 36 y 37 de la Ley $\mathrm{N}^{\circ} 21.000$ repiten la atribución genérica de potestades sancionatorias al margen de cualquier forma de tipicidad. Consideremos ahora solo un ejemplo en lo procesal. Ocurre que en algunos casos, especialmente cuando se trata de imputaciones de abuso de información privilegiada, la prueba testimonial puede resultar fundamental para la clarificación de los hechos. El regulador ha sostenido hasta ahora que la comparecencia de los testigos de descargo - a diferencia de lo que ocurre con los testigos que sustentan la imputación de la autoridad- es asunto del supuesto infractor y que, por lo tanto, si esos testigos se niegan a comparecer, no pueden ser apercibidos ni compelidos a hacerlo. La nueva ley mantiene esta situación de abierta desigualdad de armas.

Todos los esfuerzos legislativos mencionados y algunos otros comprenden, sin embargo, una ínfima parte del derecho sancionatorio de la administración. Pues prácticamente no

\footnotetext{
${ }^{53}$ CS, Oficio $\mathrm{N}^{\circ} 172-2016$ de 5.XII.2016, cons. $9^{\circ}$.

${ }^{54}$ CS, Oficio $\mathrm{N}^{\circ} 172-2016$ de 5.XII.2016, cons. $9^{\circ}$.
} 
VAN WEEZEL, Alex "Sobre la necesidad de un cambio de paradigma en el derecho sancionatorio administrativo".

existe servicio público que se precie que carezca de facultades sancionatorias, desde el Servicio Nacional de Aduanas hasta el Banco Central, pasando por el Consejo para la Transparencia. Muchas de estas potestades se superponen, como ocurre con las atribuciones de la Inspección del Trabajo y de la Secretaría Regional Ministerial de Salud en el caso de los accidentes laborales. La gran mayoría de estas sanciones se impone tras un procedimiento que con benevolencia se puede calificar de "básico" y con estándares de fundamentación que con la misma benevolencia pueden considerarse precarios. Para no abusar de la paciencia del lector referiré solamente dos ejemplos.

Es habitual que tras un accidente laboral con resultados de cierta gravedad se imponga, con total independencia de sus causas, una sanción administrativa a la empresa. El funcionario instructor de la Inspección del Trabajo o de la Secretaría Regional de Salud casi siempre hará el hallazgo de algún incumplimiento legal o reglamentario que pueda relacionarse, aun remotamente, con las causas del accidente. La materialización del derecho vuelve prácticamente imposible demostrar un comportamiento intachable, sea por la cantidad de preceptos y reglas, sea por el contenido general o incluso vago de muchas de ellas. De muy poco sirve al empleador demostrar la aplicación efectiva de medidas de seguridad, acreditar la capacitación del trabajador, acompañar fotografías de la señalética existente, etc.

En un caso en el cual un trabajador de una empresa contratista de aseo cayó desde una altura de diez metros resultando gravemente lesionado, se demostró que al momento de la caída no llevaba puesto el arnés de seguridad que correspondía -su compañero sí lo llevaba- y que la caída se produjo porque pisó sobre unas planchas de techumbre no aptas para resistir peso en lugar de pisar sobre el pasillo destinado a la circulación, el cual además contaba con baranda a un costado. Según los antecedentes acompañados por la empresa y aceptados por el Servicio, no solo existía señalética en el lugar, sino que el trabajador accidentado había recibido capacitación específica sobre los riesgos en cuestión. Se acreditó además la supervisión de los trabajos y la utilización del sistema de permisos de trabajo seguro, suscritos por las entidades supervisoras. Sin embargo, la Secretaría de Salud de la Región Metropolitana sancionó de todos modos a la empresa para la cual se prestaban los servicios de aseo (ni siquiera a la empresa contratista) por infracción del Decreto Supremo 594/99 del Ministerio de Salud, considerando los antecedentes aportados por la empresa como simples atenuantes ${ }^{55}$.

La resolución no contiene razonamiento alguno que se haga cargo de las defensas esgrimidas y se limita a repetir al pie de la letra el acta manuscrita de la funcionaria fiscalizadora que sirvió para incoar este singular procedimiento. Probablemente el mayor rendimiento argumentativo del texto consiste en sostener que el trabajador debió "haber sido fiscalizado por parte de la empresa en la cual se encontraba" y que esta fiscalización debe ser efectuada "por personas de mayor rango o jerarquía dentro de la empresa o establecimiento y ejercida en forma contigua o cercana - la que debe entenderse en el sentido de proximidad funcional entre quien supervisa o fiscaliza y quien ejecuta la labor" ${ }^{256}$. Pero en este caso la resolución ni siquiera afirma -salvo al reproducir el acta de

\footnotetext{
${ }^{55}$ Resolución Exenta N²933 (28.IV.2016), Secretaría de Salud, Región Metropolitana.

${ }^{56}$ Resolución Exenta N 2933 (28.IV.2016), Secretaría de Salud, Región Metropolitana.
} 
Polít. crim. Vol. 12, No 24 (Diciembre 2017), Art. 9, pp. 997-1043.

[http://www.politicacriminal.cl/Vol_12/n_24/Vol12N24A9.pdf]

fiscalización- que en el caso concreto no hubiera existido esta supervisión o fiscalización, y no podía hacerlo, pues ningún antecedente objetivo o declaración permite concluir o suponer su ausencia ${ }^{57}$.

El otro ejemplo procede de la regulación bancaria. El artículo 22 de la Ley General de Bancos (Decreto Ley $\mathrm{N}^{\circ}$ 1.097, de 1975) dispone que las multas que aplique la Superintendencia de Bancos e Instituciones Financieras (SBIF) "serán impuestas administrativamente" al infractor. Ninguna otra regla contiene al respecto, aparte de una regulación muy somera de un recurso especial de reclamación ante la Corte de Apelaciones Santiago, al cual, dicho sea de paso, solo se accede tras enterar la totalidad de la multa cursada.

Si la Ley General de Bancos no regula un procedimiento para imponer las multas pues se limita a decir que ellas se impondrán "administrativamente", sería lógico suponer que ha de aplicarse el procedimiento administrativo contemplado en la Ley $\mathrm{N}^{\circ} 19.880$, sobre todo si, conforme al artículo $1^{\circ}$ de esta misma ley, tiene carácter supletorio. Pues bien, la SBIF insiste hasta el día de hoy en que tal regulación no se aplica a su potestad sancionatoria, lo que la faculta para imponer sanciones de plano, es decir, sin un acta de acusación o formulación de cargos precisa y comunicada al presunto infractor para que este pueda plantear defensas o alegaciones y rendir pruebas para desvirtuar las imputaciones.

La disputa del regulador bancario con el resto de las instituciones del Estado es de larga data y ha resistido incluso los embates de pronunciamientos contrarios de la Contraloría General de la República y de sentencias desfavorables de la Corte Suprema. Mientras la Contraloría General insistía en que la SBIF debía ajustar sus procedimientos a la Ley $\mathrm{N}^{\circ} 19.880^{58}$, la SBIF buscaba que la Corte Suprema declarara su inmunidad frente al órgano contralor. Sin embargo, y precisamente en una causa en que la SBIF dedujo una acción de mera certeza pretendiendo se declarara que, no siendo un servicio público ni integrando la Administración del Estado, no se encontraba sujeta a la fiscalización de la Contraloría General $^{59}$, el Supremo Tribunal resolvió todo lo contrario. A su juicio, de la interpretación armónica de diversos preceptos legales es posible colegir que la SBIF forma parte del poder ejecutivo y que la autonomía legal reconocida en su ley orgánica solo tiene

\footnotetext{
57 Tampoco la afirmación que realiza la funcionaria fiscalizadora en el acta, pues, como es obvio, ella no estaba presente en el momento del accidente, y el acta no recoge ninguna declaración o antecedente distinto de su propia inspección personal.

${ }^{58}$ Véase, por ejemplo, Dictamen $N^{\circ} 31.941$, de 23.IV.2015: "Tal actividad debe llevarla a cabo [la SBIF] conforme a las normas especiales que regulan sus funciones y a las generales que rigen la actividad de los órganos de la Administración del Estado, entre las cuales se encuentra, en el carácter de supletoria, la preceptiva de la ley $\mathrm{N}^{\circ} 19.880$ sobre Bases de los Procedimientos Administrativos que Rigen los Actos de los Órganos de la Administración de Estado, cuyas disposiciones, según lo ordena su artículo $2^{\circ}$ son aplicables a los servicios públicos creados para el cumplimiento de la función administrativa"; el criterio fue reiterado recientemente frente a la solicitud de la SBIF en orden a que se reconsideraran los dictámenes que han señalado que ese organismo se encuentra sujeto a la fiscalización de la Contraloría General de la República. El dictamen $\mathrm{N}^{\circ} 3.385$, de 14 de enero de 2016 recordó que el artículo 98 de la Constitución Política de la República dispone que corresponde a ese organismo ejercer el control de legalidad de los actos de la Administración.

${ }^{59}$ SCS 9.IV.2015, Rol N 2.433-2015.
} 
VAN WEEZEL, Alex "Sobre la necesidad de un cambio de paradigma en el derecho sancionatorio administrativo".

como efecto desvincular al órgano de los centros de decisión de otros organismos estatales, "motivo por el cual debe estarse a la interpretación que el ente contralor efectúa en el ejercicio de sus atribuciones" 60 .

Resulta ilustrativo considerar, sin embargo, que nada de ello impidió a la SBIF, con posterioridad a este fallo, imponer de plano las multas más altas de su historia a una institución fiscalizada ${ }^{61}$.

Estos ejemplos ponen por contraste de manifiesto que, como advertía la Corte Suprema respecto del proyecto que se convirtió en la Ley $\mathrm{N}^{\circ} 21.000$, por mucho que el legislador y el Tribunal Constitucional se esfuercen en dotar al derecho sancionatorio administrativo de los resguardos mínimos del debido proceso, hay aspectos fundamentales en los que este derecho sancionatorio nunca podrá emular al derecho penal. Probablemente el más relevante de todos es el despliegue institucional asociado a la imposición de una sanción penal, que comienza con los procedimientos policiales -lectura de derechos, atribuciones limitadas a los casos de flagrancia, etc.-, sigue con los procedimientos de investigación autorizaciones judiciales, obligaciones de registro del Ministerio Público, protección de víctimas y testigos, etc.-, y continúa con la existencia de un servicio gratuito de defensa de los imputados, el pronunciamiento judicial sobre los medios de prueba que pueden pasar al juicio oral, las aprobaciones judiciales que requieren las salidas alternativas, el derecho a ser juzgado por un tribunal compuesto por tres jueces, el elevado estándar de convicción condenatoria, el régimen recursivo, etc. Nada de esto es comparable con un proceso sancionatorio conducido por la administración, y además resultaría completamente disfuncional que lo fuera.

Asimismo, ningún aparato procedimental puede compensar la ausencia de determinación que caracteriza actualmente a las infracciones administrativas.

La equiparación sustancial del derecho sancionatorio administrativo al derecho penal ha fomentado una expansión del primero que hoy se traduce en su omnipresencia y en la severidad de las sanciones -especialmente las multas y las inhabilidades- que es posible aplicar. En este contexto se entienden las demandas de aplicación de las garantías penales al derecho sancionatorio administrativo. Si el legislador ha configurado el derecho sancionatorio administrativo como si fuera un "hermano pequeño" del derecho penal, mientras el derecho administrativo no desarrolle estándares apropiados al menos para la herramienta sancionatoria - para lo cual primero debe estar en condiciones de distinguirla

\footnotetext{
${ }^{60}$ En el mismo sentido SCA Santiago, 26.XII.2014, Rol № 3.9512014.

${ }^{61}$ Carta $\mathrm{N}^{\circ}$ 16.191, de 30.XII.2015; las tres multas suman a $\$ 21.764 .507 .494 .-$ Hago presente que me ha correspondido participar en la defensa jurídica de la institución sancionada. La sanción fue dejada sin efecto por la Iltma. Corte de Apelaciones de Santiago con fecha 31 de agosto de 2016, basándose precisamente en la ausencia de un debido proceso. La SBIF recurrió de queja ante la Excma. Corte Suprema; a la fecha en que se escriben estas líneas esta acción disciplinaria se encuentra pendiente de fallo.
} 
Polít. crim. Vol. 12, No 24 (Diciembre 2017), Art. 9, pp. 997-1043.

[http://www.politicacriminal.cl/Vol_12/n_24/Vol12N24A9.pdf]

del resto de las herramientas de enforcement ${ }^{62}-$, se encontrará pragmáticamente justificada la invocación de las garantías penales, así sea "con matices" o en forma atenuada.

Por eso, otra forma de equivocar el camino sería propugnar sin más una especie de emancipación del derecho sancionatorio de la administración respecto de las garantías penales $^{63}$. En realidad, se trata de un dilema: la aplicación de las garantías penales ha fomentado y fomenta un derecho sancionatorio administrativo omnipresente y punitivista, que es preciso limitar con esas mismas garantías. Pero estas limitaciones pueden ser contrarias a los fines del derecho sancionatorio administrativo, a las consideraciones de eficacia que el legislador tuvo en mente cuando optó por utilizar la potestad sancionatoria de la administración en lugar del derecho penal. Por lo tanto, es preciso introducir "matices" a las garantías penales, lo que a su vez las vuelve nominales y, al mismo tiempo, fomenta la expansión y dureza de las sanciones administrativas.

\section{Necesidad de superar el dilema}

La situación dilemática que se ha descrito debe ser superada. Para ilustrar esta necesidad puede ser útil situarse en un escenario hipotético. Resulta que es muy tentador propiciar una "retirada" del derecho penal desde el ámbito económico y de los mercados regulados con el fin de someter tales ámbitos al régimen del "hermano pequeño", un derecho sancionatorio de tipo contravencional. Si los delitos económicos más graves relacionados con un determinado sector -mercado, industria, actividad, etc.- dejan de ser delitos y pasan a ser contravenciones, entonces todos los ilícitos relativos a ese ámbito serán investigados y sancionados por un mismo equipo de personas, o por equipos técnicos compuestos por ocho o diez funcionarios en cada sector de regulación, todos ellos instalados en la administración.

Estos ilícitos quedarían además sometidos al principio de oportunidad en la persecución, es decir, se perseguirían en forma selectiva sobre la base de decisiones no sujetas a control de legalidad. De este modo, el gobierno de turno podría imponer sus propias políticas de persecución, acordes con sus prioridades programáticas, alterando o revirtiendo las políticas del gobierno anterior. La ejecución de un programa de gobierno contaría así, más que nunca, con el respaldo de las potestades sancionatorias.

El cambio de sede permitiría asimismo flexibilizar significativamente los presupuestos de la imputación de las infracciones. Resultaría mucho más simple condenar, pues si no existe

\footnotetext{
${ }^{62}$ Contra ello conspiran las concepciones excesivamente amplias de la sanción administrativa y los modelos teóricos que impiden reconocer la especificidad de lo sancionatorio: véase supra nota $\mathrm{n}^{\circ} 18 \mathrm{y}$ el texto en torno a ella.

${ }^{63}$ En el sentido del texto ya en 1960 Novoa Monreal, uno de los principales defensores de la distinción cualitativa entre derecho penal y derecho sancionatorio administrativo: "La proliferación actual de leyes penales administrativas y la mayor gravedad que gradualmente van asumiendo las sanciones que ellas establecen (...) hace aconsejable que el legislador se preocupe de rodear a la aplicación del Derecho Penal Administrativo de garantías semejantes a las que están incorporadas al Derecho Penal, como forma adecuada de mantener el respeto por la dignidad y los derechos del hombre" (NOVOA MONREAL, Curso, cit. nota $\mathrm{n}^{\circ} 2$, p. 40).
} 
VAN WEEZEL, Alex "Sobre la necesidad de un cambio de paradigma en el derecho sancionatorio administrativo".

exigencia alguna de determinación, se abre un amplio campo para la creatividad de los aplicadores en cuanto a las posibles conductas sancionables. Por otro lado, no sería necesario lidiar con problemas de imputación subjetiva, como la exigencia de que el regulado haya obrado con dolo, tan molesta para la persecución de la criminalidad económica. Tampoco habría problemas con la superposición de sanciones que afectan a la persona jurídica y a la persona que encarna el órgano en virtud del cual aquella actuó.

Como a la vez se trata del mismo ius puniendi del Estado, las sanciones pecuniarias pueden ser muy sustanciosas. En efecto, se podría sostener que el derecho sancionatorio administrativo ya se encuentra revestido de toda clase de garantías procesales -el legislador y el Tribunal Constitucional se han esmerado en este sentido-, de modo que no existe peligro o amenaza para los derechos que obligue a obrar con particular sobriedad o recato al momento de determinar las sanciones. Además, si el derecho sancionatorio administrativo y el derecho penal son sustancialmente lo mismo, se dice, en principio no podría haber superposición o acumulación de sanciones sin infracción del principio non bis in idem $^{64}$. En consecuencia, el legislador habría depositado precisamente en manos de la administración la oportunidad para imponer una sanción pronta y "ejemplarizadora”.

Presupuestos de imputación relajados, proceso e instituciones de costo reducido, multas de gran entidad. Es el colmo de la eficiencia sancionatoria. La tentación de adoptar un modelo semejante es tan grande, que sistemas jurídicos que cuentan con bastantes más recursos que el chileno parecen estar cediendo a ella. En el caso del derecho alemán, Mühlenfeld identificaba ya en 2010 una serie de rasgos reveladores de la misma tendencia, aunque expresada en la incorporación al derecho penal de la racionalidad propia del derecho sancionatorio administrativo: la utilización, en el ámbito de los delitos económicos, de reglas extremadamente flexibles para la determinación que inicialmente estaban pensadas solo para las meras contravenciones (p. ej., en el § 81 IV 2 GWB); una ampliación y reforzamiento de las reglas sobre comiso e incautación indefinida de bienes; una ampliación del ámbito sujeto al principio de oportunidad, con amplias facultades discrecionales de la Fiscalía para imponer condiciones gravosas que funcionan como verdaderas penas sin previa condena ( $\$ 153 \mathrm{a}$ StPO); y la introducción de los daños punitivos en el ámbito de las acciones civiles derivadas del ilícito. Esta evolución lleva al autor citado a destacar la expansión de lo que denomina "pena informal", es decir, de

\footnotetext{
${ }^{64}$ Con respecto al argumento de fondo véase supra nota 26. Sobre la aplicación de este principio en el concurso entre delitos e infracciones administrativas véase recientemente GARCÍA CAVERO, Percy, "El principio del ne bis in idem material en caso de concurrencia de pena y sanción administrativa", Política Criminal, Vol. 11, No 21 (Julio 2016), pp. 21-33. (pp. 27 y ss.); también para quienes, como este autor, asumen una diferencia sustancial entre ambas clases de sanciones, consideraciones de proporcionalidad obligan a utilizar un "principio de cuenta", de modo que se descuente de una sanción la privación de derechos ya impuesta por medio de la otra. Para quienes no asumen una diferencia sustancial, las únicas restricciones posibles son las que derivan de la proporcionalidad o prohibición de exceso: cfr. MAÑALICH, Juan Pablo, "El principio ne bis in idem frente a la superposición del derecho penal y el derecho administrativo sancionatorio", Política Criminal, Vol. 9, № 18 (2014), pp. 543-563 (esp., pp. 558 y ss.). Constituye una advertencia sobre la capacidad de rendimiento de este principio, sin embargo, la investigación reciente de RIOFRÍO MARTÍNEZ-VILLALBA, J. C., "Alcance y límites del principio de proporcionalidad", Revista Chilena de Derecho, Vol. 43, No 1 (2016), pp. 283-309.
} 
Polít. crim. Vol. 12, No 24 (Diciembre 2017), Art. 9, pp. 997-1043.

[http://www.politicacriminal.cl/Vol_12/n_24/Vol12N24A9.pdf]

genuinas sanciones que se imponen sin que exista una condena, pero que al mismo tiempo se presentan como la consecuencia de un proceso penal ${ }^{65}$.

El resultado de una evolución como la imaginada - con independencia de si se traduce en la expansión del derecho sancionatorio administrativo o en una administrativización del derecho penal- sería negativo para los derechos y libertades de las personas, pues se cambiaría un sistema construido en torno a las garantías por un sistema construido en torno a la eficacia y la eficiencia ¿Qué tan avanzado se encuentra este proceso en Chile? Aparte de los síntomas ya analizados, es posible observar algunas manifestaciones claras de confusión entre el derecho penal y el derecho sancionatorio administrativo. Por ejemplo, la mezcla del derecho de faltas - es decir, de las bagatelas- con el derecho aplicable a sanciones pecuniarias de elevada cuantía: mientras el derecho sancionatorio administrativo ignora por completo los límites de cuantía establecidos para las multas administrativas en el artículo $501 \mathrm{CP}$, se aplica a las contravenciones el plazo de prescripción de seis meses que el Código Penal estableció para las faltas (artículo 94 del Código Penal).

¿Cuáles son los pasos siguientes? Posiblemente la introducción de reglas duras sobre comiso administrativo junto a reglas que permitan a los particulares demandar perjuicios cuando no daños punitivos- ya en el contexto del mismo proceso administrativo sancionador, es decir, sin necesidad de que la obligación de indemnizar sea establecida en una sentencia judicial. En esta dirección apuntaba precisamente el proyecto para modificar la Ley N ${ }^{\circ}$ 19.496, sobre Protección de los Derechos de los Consumidores en su versión original $^{66}$.

El dilema al que se ha hecho referencia debe ser superado, además, en aras de la eficacia del derecho penal. La realidad de los delitos económicos es compleja y su persecución tiene que ver con los costos que la sociedad está dispuesta a asumir para investigar esta clase de hechos, enjuiciarlos y luego ejecutar una eventual condena. Hoy resulta evidente para cualquier observador que la comisión de delitos económicos y patrimoniales graves no lleva asociada el cumplimiento de una condena efectiva. A los autores de ciertos ilícitos "les conviene" que los condenen pronto para poder disfrutar tranquilamente, y en libertad, del producto de los hurtos y defraudaciones que han cometido.

La investigación de los delitos económicos y patrimoniales no es particularmente compleja, pero es costosa en tiempo y recursos. Por lo general implica acopiar una cantidad importante de documentos, realizar informes periciales que los ordenen y sitúen en su contexto, y entrevistar a un número considerable de testigos. Si esto se lleva a un juicio

\footnotetext{
${ }^{65}$ MÜHLENFELD, Leonhard, Die informelle Strafe im deutschen und europäischen Wirtschaftsstrafrecht, Berlin: Wissenschaftlicher Verlag Berlin, 2010; una síntesis de su planteamiento puede leerse en pp. 22-37.

${ }^{66}$ En su estado actual de tramitación (Artículo $50 \mathrm{~N}$ letra c] de la versión comparada correspondiente al Segundo Informe de la Comisión de Economía del Senado), la propuesta contempla una fórmula muy atenuada conforme a la cual, en la misma resolución que pone término al procedimiento sancionatorio ante el SERNAC, podrá ordenarse "la restitución de los cobros que hubieren tenido lugar con infracción a la presente ley, con reajustes e intereses". De este modo se deja en manos del SERNAC la parte más fácilmente determinable del daño emergente, mientras que el tribunal debe ocuparse de los perjuicios de más difícil determinación y del lucro cesante.
} 
VAN WEEZEL, Alex "Sobre la necesidad de un cambio de paradigma en el derecho sancionatorio administrativo".

oral, el sacrificio de tiempo y, a veces, también de la paciencia de los presentes, es enorme. Cabe recordar por ejemplo que, en principio, cada uno de los documentos que se incorpora al juicio debe ser leído en su totalidad. Por otro lado, si se aspira a recuperar bienes, la investigación debe iniciarse en forma inmediata. Esto implica que el fiscal debe formalizarla con prontitud, pues de lo contrario tendrá dificultades para indagar los movimientos que los imputados pudieran haber realizado sirviéndose de mecanismos protegidos del sistema financiero.

Pero para estar en condiciones de formalizar pronto la investigación y solicitar fundadamente diligencias intrusivas se requiere tiempo, trabajo y motivación. El problema es que, incluso tras una investigación exitosa, las posibilidades de obtener una pena de cumplimiento efectivo están muy restringidas por la ley, de modo que con frecuencia carece de sentido optar por un juicio oral en lugar del juicio abreviado. Entonces, ¿para qué tomarse la molestia de investigar un delito, especialmente si los recursos son escasos y hay tantas otras causas que tramitar? Si el desenlace de un caso que se lleva a juicio puede ser equivalente o incluso más beneficioso para el imputado que una salida negociada, y esta última no requiere una investigación real de los hechos, ¿qué sentido tienen el esfuerzo y los costos de una investigación?

La consecuencia de todo esto es que al parecer hay dos formas posibles de expansión del derecho sancionatorio administrativo, una indeseable y otra que podría ser urgente abordar. Indeseable es la que pretende sustituir al derecho penal en los ilícitos más graves. Urgente, en cambio, es una que permita liberar recursos del sistema penal para ocuparse precisamente de esos ilícitos más graves, en particular en el ámbito económico y patrimonial.

En efecto, los problemas descritos - que no son exclusivos de la realidad chilena- llevan a pensar en la construcción de un modelo escalonado de reacción frente a los ilícitos económicos y patrimoniales. Este modelo podría tener una estructura piramidal, donde la base de la pirámide esté conformada por muchas infracciones que hoy son penales y que podrían pasar a ser administrativas y, por lo mismo, quedar sujetas a los mecanismos y al régimen propio del derecho sancionatorio administrativo. En este nivel podrían estar $-\mathrm{y}$, en parte, ya están- ciertas zonas de ilicitud en materia de mercado de valores, de libre competencia, en el ámbito tributario, algunas formas específicas de deslealtad en la administración de negocios ajenos, etc. Este proceso de depuración del derecho penal permitiría reservarlo para los ilícitos más graves $\mathrm{y}$, entonces, hacerlo seriamente: con capacidad real de persecución y con penas adecuadas, que excluyan en principio la aplicación de los regímenes legales pensados para las bagatelas o las infracciones de menor entidad $^{67}$.

\footnotetext{
${ }^{67}$ Una lógica similar a esta, aunque en términos mucho más embrionarios, tuvo que ver con el surgimiento de la ordenanza alemana de contravenciones. Así lo relatan GÜRTLER, Franz; SEITZ, Helmut, en: GÖHLER, Erich, Ordnungswidrigkeitengesetz, München: C. H. Beck, 16 a ed. 2012, Einleitung, nn. 2 y ss.
} 
Polít. crim. Vol. 12, № 24 (Diciembre 2017), Art. 9, pp. 997-1043.

[http://www.politicacriminal.cl/Vol_12/n_24/Vol12N24A9.pdf]

\section{Un derecho sancionatorio administrativo configurado según sus fines}

Ahora es preciso preguntarse cómo debería estar configurado el derecho sancionatorio administrativo para que responda adecuadamente a sus fines o, con el lenguaje de la Corte Suprema, para que la potestad administrativa sancionatoria no se desnaturalice, perdiéndose la intención y fines que el legislador tuvo en consideración al momento de recurrir a ella ${ }^{68}$. Tal intención y fines no son otros que dotar de eficacia a la regulación de las distintas materias, incluyendo por cierto las instituciones jurídicas propias de cada ámbito de regulación.

$\mathrm{Si}$, como se ha visto, el derecho sancionatorio administrativo es, de lege lata, distinto del derecho penal y su fin es el buen funcionamiento sectorial a futuro, entonces tal derecho sancionatorio debería ser muy distinto de lo que actualmente es. Y en un derecho sancionatorio administrativo configurado realmente para conseguir sus fines de eficacia y buen funcionamiento de la regulación sectorial, basta con el régimen de garantías que emana del principio de necesidad de la sanción y de los principios fundamentales del debido proceso -incluyendo la previsibilidad de las sanciones-, sin que sea necesario echar mano de las "garantías penales". Este es, a mi juicio, el comienzo de la solución del dilema. Esbozo a continuación algunas configuraciones de lege ferenda para cuando exista disposición de enmendar el rumbo y con el ánimo de fomentar esa misma disposición. Todas ellas tienen en común que apuntan a dejar atrás el modelo punitivista actualmente vigente para reemplazarlo por un modelo en que el derecho sancionatorio administrativo sea un verdadero instrumento para la elevación de estándares de conducta hacia el futuro.

\subsection{Evitar las infracciones basadas en discrepancias interpretativas}

\subsection{1. Áreas de administración centralizada de los riesgos}

En principio, el derecho sancionatorio administrativo debe operar solo respecto de contravenciones análogas a las infracciones de tránsito. Es decir, solo debería ser procedente la imposición de sanciones administrativas en ámbitos en que el legislador pretende administrar centralizadamente los riesgos. En cambio, no debería operar en materias que admiten interpretaciones divergentes e igualmente plausibles o, allí donde la ley las admite, sin que la ambigüedad haya sido suprimida ex ante a través de interpretaciones vinculantes. Esto significa que no es un ámbito propio del derecho sancionatorio administrativo aquél en el cual el legislador ha querido precisamente que exista un ámbito de apreciación o interpretación particular, es decir, donde se ha instituido una administración genuinamente descentralizada de los riesgos de una determinada actividad. El derecho sancionatorio administrativo no puede castigar meras discrepancias de apreciación o interpretación entre el regulador y el regulado.

Lamentables ejemplos de lo contrario se encuentran en los ya citados casos de sanciones de la SVS por infracción del "deber de abstención" en el año 2007, cuando el mercado -al menos en términos generales- no estaba en condiciones de anticipar un cambio de criterio

${ }^{68}$ SCS 30.X.2014, Rol No 1.079-2014, cons. $9^{\circ}$. 
VAN WEEZEL, Alex "Sobre la necesidad de un cambio de paradigma en el derecho sancionatorio administrativo".

semejante, y en las sanciones impuestas por la Unidad de Análisis Financiero (UAF) por omisión del deber de informar a la unidad operaciones sospechosas. En este último ámbito ocurre que la ley define la operación sospechosa en términos tales -operaciones inusuales según los usos o costumbre de la actividad de que se trate, o carentes de justificación económica o jurídica aparente (artículo $3^{\circ}$ inciso $2^{\circ}$ de la Ley 19.913 ) ${ }^{69}$ - que pone precisamente en manos de los sujetos obligados decidir si una operación determinada califica como sospechosa. Esta decisión no es trivial, pues exige contrastar la operación con usos y costumbres de contenido muy variado, y las posibles justificaciones de un acto u operación suelen ser también múltiples. En este contexto, es una manifestación de burdo punitivismo que las eventuales discrepancias de criterio entre el sujeto obligado y la UAF que deberían ser de ordinaria administración- se tengan que resolver en el contexto de un proceso sancionatorio. Las sanciones deben quedar reservadas para aquellos ámbitos que se encuentren suficientemente formalizados en la regulación, o bien, donde se cuenta con interpretaciones vinculantes para todos los involucrados.

\subsubsection{Sanciones previa advertencia}

Allí donde sea indispensable disponer de instrumentos sancionatorios a pesar de que la ley admite varias formas de aplicación plausibles e incompatibles entre sí, y en la medida en que existan suficientes medios de fiscalización, el derecho sancionatorio administrativo debería aplicarse solo previa advertencia de índole general o individual. El fundamento de esta exigencia es muy simple: no puede haber sorpresas respecto del criterio del organismo fiscalizador. Si se trata de elevar los estándares de conducta en un determinado sector de regulación, el derecho sancionatorio administrativo no puede convertirse en el juego del gato y el ratón. En muchos casos, esto puede implicar que la primera sanción a un sujeto determinado, y por una cierta contravención, deba consistir en una amonestación por escrito.

El derecho sancionatorio administrativo chileno da cuenta de una interesante evolución en este sentido, pero también conoce todavía manifestaciones increíbles de la situación contraria. Así, por ejemplo, en el verdadero laberinto que constituye la llamada Ley de Subvenciones (DFL $\mathrm{N}^{\circ} 2$ de 1996), se establece que la fiscalización de la asistencia a clases para los programas que la exigen puede realizarse cualquier día del mes y mediante la revisión de los libros de clase (artículo 14) ${ }^{70}$. Así, se ha entendido que si los fiscalizadores

\footnotetext{
${ }^{69}$ La Ley $\mathrm{N}^{\circ} 20.818$ agregó además los actos u operaciones que "pudieran constituir" alguna de las conductas contempladas en el artículo $8^{\circ}$ de la Ley $\mathrm{N}^{\circ} 18.314$, o sea realizada por una persona natural o jurídica que figure en los listados de alguna resolución del Consejo de Seguridad de las Naciones Unidas. Esta última hipótesis reviste cierta precisión -aunque sea cuestionable por otras razones- y representaría, según se expone en el texto, un ámbito idóneo para la potestad sancionatoria de la administración. La primera hipótesis, sin embargo, es un paradigmático ejemplo de exceso o desproporción. El artículo $8^{\circ}$ de la Ley Antiterrorista tipifica del modo más amplio posible conductas de financiamiento del terrorismo: ¿cómo podría advertir un sujeto obligado de los que señala el artículo $3^{\circ}$ de la Ley $\mathrm{N}^{\circ} 19.913$ que las inversiones o los pagos que recibe "pudieran constituir" alguna forma de financiamiento del terrorismo? ¿Debe contar cada sujeto obligado, para no exponerse a las sanciones de la UAF, con una agencia de inteligencia más eficaz que las agencias estatales, que por lo general no son capaces de advertir lo anterior?

70 "Se entenderá: a) Por discrepancia de un establecimiento educacional en una fecha determinada, la diferencia entre la asistencia observada por el inspector en una visita efectuada en esa fecha a dicho
} 
Polít. crim. Vol. 12, No 24 (Diciembre 2017), Art. 9, pp. 997-1043.

[http://www.politicacriminal.cl/Vol_12/n_24/Vol12N24A9.pdf]

aparecen el día lunes después de vacaciones y fin de semana largo -digamos, a la vuelta del 18 de septiembre-, la asistencia que constaten en los libros del día será comparada con la asistencia promedio del mes informada por el establecimiento. Si no coinciden, se impone una sanción de descuento en la subvención, aunque la asistencia promedio del mes informada sea correcta. Este ejemplo no es ficticio ${ }^{71}$.

Una evolución positiva se manifiesta, en cambio, en reglas como las del inciso $2^{\circ}$ del artículo 78 de la Ley $\mathrm{N}^{\circ} 20.529$, sobre Sistema de Aseguramiento de la Calidad de la Educación, que establece las infracciones leves: "Estas infracciones solo serán sancionadas si no fueren subsanadas en el plazo que prudencialmente conceda al efecto el fiscalizador de la Superintendencia". El procedimiento sancionatorio sirve efectiva e inmediatamente para obtener un mejoramiento del estándar ${ }^{72}$.

En esta misma línea, la publicidad de las sanciones que impone la administración, que ha comenzado a practicarse en diversos sectores, es una exigencia mínima para la consecución de los objetivos del derecho sancionatorio administrativo. Lamentablemente, el artículo 21 de la Ley $\mathrm{N}^{\circ} 19.628$ establece una restricción que conspira contra este propósito, cuando dispone que los organismos públicos que sometan a tratamiento datos personales relativos a condenas por infracciones administrativas no podrán comunicarlos una vez que se haya cumplido la sanción. De este modo queda vedado el acceso a las resoluciones sancionatorias relativas a personas naturales ${ }^{73}$.

\subsection{Alternativas a la imposición de la sanción y sanciones convenidas}

Debería reconocerse la amplia procedencia de una figura análoga a la "suspensión condicional del procedimiento", donde se permita acordar condiciones que importen la sujeción de la persona o empresa a estándares más elevados de conducta en orden a la prevención de riesgos de incumplimiento. La negociación y el marco general de estas condiciones deberían estar claramente regulados - probablemente en forma sectorial-, y su

establecimiento y la asistencia media declarada por el sostenedor en el mes correspondiente, dividida por este último valor y expresada como porcentaje. Esta será positiva cuando la asistencia media declarada sea mayor que la observada y negativa en caso contrario".

${ }^{71}$ Cfr. Resol. Exenta N URS-13/148, de 21.X.2013, emanada de la Secretaría Regional de Educación de la Región Metropolitana.

${ }^{72} \mathrm{El}$ inciso $2^{\circ}$ del artículo $50 \mathrm{~N}$ del proyecto para la reforma de la Ley $\mathrm{N}^{\circ}$ 19.496, sobre Protección de los Derechos de los Consumidores contempla también una institución análoga: "Tratándose de las empresas proveedoras comprendidas en la clasificación del inciso segundo del Artículo Segundo de la ley $\mathrm{N}^{\circ} 20.416$ y siempre que no se hubieren configurado las agravantes señaladas en las letras a) y b) del inciso quinto del artículo 24, las multas a que se refiere la letra b) de este artículo serán reemplazadas por la participación obligatoria del titular o representante legal de la empresa de menor tamaño, y/o de uno o más de sus trabajadores, en un programa de capacitación sobre derechos y deberes de los consumidores realizado por el Servicio Nacional del Consumidor.// Sustituida la multa de conformidad a lo dispuesto en el inciso precedente, si el obligado, no participare en el programa de capacitación correspondiente, procederá el aumento de la multa originalmente determinada, el que no podrá exceder de un $25 \%$ de su valor".

${ }^{73}$ Así lo ha resuelto también recientemente la Contraloría General de la República respecto de las sanciones que impone la SVS: "Tratándose de las sanciones que la SVS aplique a personas naturales, dicho organismo deberá observar lo dispuesto en el citado artículo 21 de la ley $\mathrm{N}^{\circ} 19.628$, para efectos de la realización o mantención de las publicaciones por las que consulta" (Dictamen No 28.089 de 14.IV.2016. 
VAN WEEZEL, Alex "Sobre la necesidad de un cambio de paradigma en el derecho sancionatorio administrativo".

establecimiento debería contar con aprobación judicial, al menos en los casos en que resulten particularmente invasivas o restrictivas de derechos.

La Ley $\mathrm{N}^{\circ} 20.417$ de 2010, que, entre otras materias, contiene la ley orgánica de la Superintendencia del Medio Ambiente (artículo $2^{\circ}$ ), estableció un mecanismo de suspensión del procedimiento sancionatorio sujeto a condiciones ${ }^{74}$. Así, dispone el artículo 42 de la ley orgánica que una vez iniciado un procedimiento sancionatorio y en el plazo de diez días, el presunto infractor puede presentar a la autoridad un programa de cumplimiento. Este consiste en un plan de acciones y metas para dar cumplimiento satisfactorio, en un cierto plazo, a la normativa ambiental en cuestión. La aprobación del programa por parte de la Superintendencia suspende el procedimiento sancionatorio y la prescripción. Si el presunto infractor no cumple las condiciones, el procedimiento se reinicia. Cumplido el programa dentro de los plazos establecidos y de acuerdo a las metas fijadas en él, el procedimiento administrativo se da por concluido.

Si bien la regulación es perfectible -especialmente en cuanto a las condiciones para optar a la suspensión y a las sanciones en caso de incumplimiento-, se trata ciertamente de un gran avance en la adopción de una perspectiva no punitivista.

Sería deseable que este modelo se replicara en otros ámbitos, igual que el establecimiento de procedimientos simplificados para infracciones de menor gravedad, donde el presunto infractor puede reconocer responsabilidad y evitar los costos del procedimiento ordinario, como ocurre en el Párrafo $3^{\circ}$ del Título IV de la Ley $\mathrm{N}^{\circ} 21.000$ que crea la Comisión de Mercado Financiero.

\subsection{Mecanismos de autodenuncia}

Las finalidades de las sanciones administrativas son compatibles con los mecanismos de autodenuncia que surten efecto atenuante de las posibles sanciones.

La ponderación de las ventajas e inconvenientes de la autodenuncia como instrumento de política pública no es sencilla, pues tal ejercicio no se limita a un análisis de costos y beneficios reductibles a un denominador común. Aparte de las consideraciones de eficacia está en juego la forma como el Estado entiende su función y, sobre todo, la comprensión del castigo. Si este se concibe como reparación de un mal, aunque sea del mal ideal consistente en la "lesión del derecho", entonces hay que decidir si quien se delata a sí mismo - y a otros- ha reparado ese mal en la medida que la sociedad espera.

Pero si el castigo es una particular herramienta de enforcement, un mal con que se amenaza para desincentivar el ilícito, la institución de la delación es menos problemática y puede constituir una forma eficiente de administración de la potestad sancionatoria. Si hay un ámbito en el cual una regla de delación compensada bien diseñada puede funcionar en forma adecuada y con menos problemas de fundamentación que en otros es, justamente, el

\footnotetext{
${ }^{74}$ Un excelente análisis de este y otros dispositivos de la Ley $\mathrm{N}^{\circ} 20.417$ puede verse en SOTO DELGADO, "Sanciones administrativas", cit. nota n 19, pp. 204 y ss.
} 
derecho sancionatorio administrativo. Esta es otra razón para observar con particular atención la forma en que operará el modelo contemplado en el artículo 58 de la Ley $\mathrm{N}^{\circ} 21.000^{75}$.

Pues no se debe olvidar que el diseño de los mecanismos de autodenuncia presenta una serie de desafíos técnicos, desde su aplicabilidad a quienes son partícipes necesarios en cierto tipo de ilícitos, hasta la estructura y capacidades de los órganos encargados de hacerlos operativos, pasando por el peligro de que se abuse de la institución para dañar a los competidores, la eventual afectación del derecho a defensa de quienes resulten mencionados, el riesgo de que se presione al justiciable para que se auto inculpe, etc. La índole administrativa del procedimiento sancionatorio no inmuniza a la institución contra ninguno de estos peligros.

Además, la aplicación de la delación siempre estará sujeta a un test de proporcionalidad que podría hacerla fracasar en el caso concreto. La pregunta acerca de en qué medida es válida y suficiente en el ámbito contravencional una fundamentación pensada para los ilícitos penales más graves y la criminalidad organizada no se deja responder en términos abstractos para todos los casos posibles.

\subsection{Orientación a la prevención de riesgos futuros}

Las sanciones administrativas deberían estar siempre ordenadas a la prevención de riesgos futuros. No se trata de un asunto de magnitud o aflictividad del castigo: las sanciones pueden muy ser relevantes y costosas para el sancionado, pero siempre han de ser tales que importen un mejoramiento efectivo del estándar defectuoso que dio lugar a su imposición. Ello implica que el régimen jurídico de las sanciones debe considerar facultades suficientes para establecer programas de mejoramiento diseñados por comisiones de expertos en el respectivo ámbito de regulación. Estas comisiones, que asesoran a la autoridad en el aspecto más crucial de la imposición de la sanción, deberían ser establecidas por ley o contar con base legal.

La teoría y praxis de la llamada "responsabilidad penal" de las personas jurídicas puede aportar significativamente en este aspecto ${ }^{76}$. La práctica sancionatoria contra empresas implica enfrentar problemas y riesgos muy variados, desde la imposición de un castigo inmerecido a los minoritarios hasta la puesta en peligro de los puestos de trabajo. El debate reciente sobre la materia en los Estados Unidos sugiere que el sistema de determinación de la pena empresarial debe contar con espacios adecuados para una especie de casuismo orientado técnicamente, en donde se ponderen los diversos intereses en juego. Este ejercicio se deja en manos de comisiones técnicas de determinación de la sanción. El trasfondo teórico de esta configuración del sistema de penas es la idea de que no se trata de optar

\footnotetext{
${ }^{75}$ Aunque tanto este modelo como el incorporado en el Decreto Ley $\mathrm{N}^{\circ} 211$ por la Ley $\mathrm{N}^{\circ} 20.361$ presentan la particularidad de que la delación compensada está llamada -en un grupo significativo de casos- a producir efectos en sede penal, al menos a partir de la Ley $\mathrm{N}^{\circ} 20.945$ que estableció el delito de colusión.

${ }^{76}$ Véase al respecto SÁNCHEZ, Carlos, Problemas de determinación de la pena en la Ley $N^{\circ} 20.393$, Universidad de Chile, memoria para optar al grado académico de Licenciado en Ciencias Jurídicas y Sociales, Santiago, 2013, pp. 137 y ss.
} 
VAN WEEZEL, Alex "Sobre la necesidad de un cambio de paradigma en el derecho sancionatorio administrativo".

entre regulación y no regulación ${ }^{77}$, sino de encontrar formas de regular que fomenten la cooperación entre instituciones públicas y privadas también cuando se trata de la imposición y aplicación de sanciones.

En esta línea se ha hablado de un modelo de intervención escalonado o enforcement pyramid, en el que

"una infracción debe dar lugar en primer término a métodos de persuasión informales y amonestaciones. El segundo escalón lo conformaría la imposición de sanciones administrativas; el tercero la realización, de acuerdo con una autoridad o un tribunal o bajo su supervisión, de investigaciones internas y la imposición de responsabilidades individuales mediante procesos disciplinarios; el cuarto la imposición de sanciones penales (...) el sexto nivel lo conformarían las sanciones penales más graves tales como las interdictivas o la disolución, que sería la sanción a imponer en aquellos casos en los que la prevención general no funciona debido a la incompetencia de los directivos de la entidad para cumplir con la ley". ${ }^{78}$

Una de las consecuencias más importantes de lo anterior es que la sanción de multa debería ser excepcional en el derecho sancionatorio administrativo. Concretamente, debería quedar reservada para los casos de contumacia o incumplimiento de las condiciones o del programa de mejoramiento previamente definidos. La mera transferencia de fondos desde el infractor hacia el Fisco es ajena a la racionalidad del derecho sancionatorio administrativo en la misma medida en que calza perfectamente con el sentido y finalidad de las sanciones penales ${ }^{79}$.

77 FISSE, Brent y BRAITHWAITE, John, "The Allocation of Responsibility of Corporate Crime: Individualism, Collectivism and Accountability”, Sydney Law Review, Vol. 11 (1988), pp. 444-513 (p. 511 ).

${ }^{78}$ NIETO, Adán, La responsabilidad penal de las personas jurídicas: un modelo legislativo, Madrid: Iustel, 2008, p. 275; cfr. AYRES, Ian; BRAITHWAITE, John, Responsive Regulation, New York, Oxford: OUP, 1992, pp. 35 y ss. y passim. En Chile, véase al respecto SOTO DELGADO, "Sanciones administrativas", cit. nota $\mathrm{n}^{\circ} 19$, pp. 189 y ss., con énfasis en la institucionalidad medio ambiental. A su juicio, la "responsividad" encuentra su anclaje en exigencias constitucionales y de bases generales de la administración, enfatizando la "flexibilidad" del instrumental que esta debería tener a su disposición. Solo cabría agregar que el modelo de regulación sensible o "responsiva" no puede pasar por alto que las herramientas sancionatorias deben sujetarse a un estatuto distinto de los demás actos meramente desfavorables de la administración, lo cual Soto Delgado, en su referencia al fallo comentado en la sección 1, parece dejar en un segundo plano ("Sanciones administrativas", cit. nota $\mathrm{n}^{\circ} 19$, pp. 203 y ss.).

${ }^{79}$ La discusión sobre la idoneidad y proporcionalidad de las multas como sanciones penales es antigua y abundante: cfr. entre muchos otros, el ya clásico trabajo de COFFEE, John: "No Soul to Damn: No Body to Kick': An Unscandalized Inquiry into the Problem of Corporate Punishment”, Michigan Law Review, Vol. 79, No 3 (1981), pp. 386-459; GRUNER, Richard S., "Beyond Fines: Innovative Corporate Sentences under Federal Sentencing Guidelines”, 71 Wash. U. L. Q. (1993), pp. 261-328 (pp. 265-267); en general sobre el estado de la cuestión en el debate estadounidense véase SÁNCHEZ, Problemas de determinación, cit. nota $\mathrm{n}^{\circ}$ 76, pp. 144 y ss.; SILVA SÁNCHEZ, J. M., "Eficiencia y derecho penal”, Anuario de Derecho Penal y Ciencias Penales, t. 49 (1996), pp. 93-128. En la discusión continental se suele distinguir entre las multas impuestas a las personas naturales y las que se imponen a las personas jurídicas (cfr. por ejemplo, ACHENBACH, Hans, en: ÉL MISMO; RANSIEK, Andreas; RÖNNAU, Thomas (Eds.), Handbuch Wirtschaftsstrafrecht, Heidelberg: C.F. Müller, 4 ${ }^{\mathrm{a}}$ ed. 2015, pp. 6-20; WITTIG, Petra, Wirtschaftsstrafrecht, München: C.H. Beck, $3^{a}$ ed. 2014, pp. 105-110). Esta distinción-dogmáticamente correcta en algunos paíseses en realidad artificial, pues la multa impuesta a la persona jurídica se radica en el patrimonio de los dueños del capital, que son personas naturales actuando directamente o a través de vehículos de inversión. Por regla 
Polít. crim. Vol. 12, No 24 (Diciembre 2017), Art. 9, pp. 997-1043.

[http://www.politicacriminal.cl/Vol_12/n_24/Vol12N24A9.pdf]

\subsection{No contaminar el fin de la sanción administrativa con objetivos ajenos a ella}

\subsubsection{Control de riesgos futuros versus daño patrimonial}

Las consideraciones anteriores muestran cuán equivocada puede ser la idea de utilizar el procedimiento administrativo sancionatorio para imponer sanciones típicamente penales como el comiso -salvo en lo que respecta a objetos o instrumentos peligrosos-, o para la satisfacción en sede administrativa de pretensiones indemnizatorias. La lógica del buen funcionamiento de la regulación sectorial y la elevación de estándares hacia el futuro es ajena a la determinación del daño patrimonial causado y, sobre todo, al establecimiento jurídicamente vinculante de una relación de imputación entre una conducta por debajo del estándar y el daño sufrido por un tercero. Es precisamente este tipo de consideraciones las que no deben interferir con la función de control de peligros y aseguramiento de la eficacia regulativa que caracteriza al derecho sancionatorio administrativo. La mezcla de perspectivas conduce inevitablemente al fracaso en la realización de una de ellas o, más probablemente aun, al fracaso de ambas.

El artículo 172 de la Ley $\mathrm{N}^{\circ} 18.045$ sobre Mercado de Valores, por ejemplo, remite expresamente a las reglas generales sobre indemnización de perjuicios por las conductas de abuso de mercado asociadas a la información privilegiada. La regulación es muy curiosa, pues establece el comiso del beneficio pecuniario obtenido por el infractor y parece entender que las pretensiones indemnizatorias deben satisfacerse también con cargo a ese beneficio ("cuando no hubiere otro perjudicado"). Es decir, por un lado se impone una sanción característica del derecho penal - una forma de comiso con apariencia de multa- y, por otro, se permite al perjudicado resarcirse con cargo a los montos que comprendería esa sanción pecuniaria. Afortunadamente, la ley tuvo al menos la prudencia suficiente como para entregar el conocimiento de la pretensión indemnizatoria a la jurisdicción civil. En esta medida, puede representar un interesante esbozo de armonización de las perspectivas sancionatoria e indemnizatoria, donde el fin de la sanción no se contamina con una lógica indemnizatoria ajena a ella.

\subsubsection{Reglas de imputación diferentes}

Por las mismas razones -se trata de objetivos diferentes y, por lo tanto, de sistemas de imputación distintos-, es conveniente dejar de lado la denominada "culpa infraccional" en materia de responsabilidad extracontractual. La confusión de puntos de vista ya ha causado problemas serios en la aplicación del artículo 492 del Código Penal en causas por accidentes de tránsito, al menos cuando el "hecho ilícito" de que se trata es una contravención administrativa. Alguna jurisprudencia, basándose en la idea de la culpa infraccional, propia de la responsabilidad civil, ha sostenido que la "infracción de los reglamentos" - uno de los requisitos del tipo definido en el citado artículo 492- permite dar por establecida también, automáticamente, la concurrencia del segundo, la "mera

general, además, el impacto de la multa en el patrimonio individual del socio o accionista guarda una relación directamente proporcional con sus posibilidades para influir en las decisiones corporativas y su participación en los beneficios del ilícito. 
VAN WEEZEL, Alex "Sobre la necesidad de un cambio de paradigma en el derecho sancionatorio administrativo".

imprudencia o negligencia”. Cuando además la imprudencia se hace consistir en el hecho de no haber conducido el sujeto atento a las condiciones del tránsito, el resultado es simplemente desastroso ${ }^{80}$.

Las diferencias entre los sistemas de imputación civil, administrativo y penal conducen a que el establecimiento de los hechos probados, en uno y otro ámbito, obedezca a racionalidades completamente distintas. Por ejemplo, mientras las reglas de determinación de la pena exigen "contar delitos" en todos los casos de conductas reiteradas en el tiempo, un ilícito civil complejo puede estar compuesto por una serie de conductas que no es necesario contar, al menos en todos aquellos casos - la inmensa mayoría- en que la cantidad precisa de conductas ilícitas no es relevante para determinar la producción del daño o la causalidad.

En este sentido razona, por ejemplo, el voto de prevención de la ministra señora Rojas en la sentencia de la Corte de Apelaciones de Santiago recaída en una de las aristas tardías del denominado caso Inverlink. Se trata además de un ámbito en el que la doctrina predominante está incluso conforme con apreciar semejanzas y paralelos entre lo administrativo y lo penal. La sentencia se refiere a una causa por delito del artículo 53 inciso $2^{\circ}$ de la Ley $\mathrm{N}^{\circ} 18.045 \mathrm{y}$, entre sus considerandos, transcribe in extenso una resolución sancionatoria de la SVS en contra de las personas ahora condenadas penalmente. Luego concluye: "Ha sido entonces, la Superintendencia de Valores y Seguros, autoridad fiscalizadora del Mercado de Valores, la que en una acuciosa investigación concluyó de la forma que lo hace, confirmando que se infringió por los encausados la ley 18.045", lo que permitiría tener por establecida la infracción también en el ámbito penal ${ }^{81}$. La ministra señora Rojas discrepa de ello en su prevención, donde sostiene que "no comparte el motivo vigésimo sexto, toda vez que la sanción administrativa que la Superintendencia aplicó a la Corredora no dice relación con este proceso en que se persigue la responsabilidad penal de los funcionarios de la Corredora y de CORFO, de modo que éste solo puede tenerse como uno de los elementos de convicción y no como fundamento de la existencia del ilícito ni de la participación de los encausados". Nada hay que agregar a esta afirmación ${ }^{82}$.

\subsection{Sanciones en función de los programas de cumplimiento}

Los elementos anteriores conducen a realzar la importancia de los programas de cumplimiento. Estos programas y el contexto de combinación entre regulación estatal y autorregulación en el cual se inscriben ("autorregulación regulada") han ido adquiriendo,

${ }^{80}$ SCS 10.XI.2005, Rol $\mathrm{N}^{\circ} 853-2003$, cons. $10^{\circ}$. El criterio se reitera en otras sentencias, como SCS 4.VI.2008, Rol No 434-2008, cons. $8^{\circ}$.

${ }^{81}$ SCA Santiago 2.XII.2014, cons. $26^{\circ}$.

${ }^{82}$ El proyecto para modificar la Ley $\mathrm{N}^{\circ} 19.496$, sobre Protección de los Derechos de los Consumidores (Boletín $\mathrm{N}^{\circ}$ 9369-03) contemplaba una propuesta en la dirección contraria, precisamente para imponer por ley aquello que el sentido jurídico resiste: "En los juicios de indemnización de perjuicios seguidos en contra de quien hubiere sido, previamente, sancionado por una infracción a la presente ley, encontrándose la resolución sancionatoria firme, no podrán tomarse en consideración pruebas o alegaciones incompatibles con la declaración de existencia del hecho que constituyó la infracción ni con el establecimiento de la participación del sancionado en la misma" (artículo $50 \mathrm{~A}$, nuevo, del proyecto original). 
Polít. crim. Vol. 12, No 24 (Diciembre 2017), Art. 9, pp. 997-1043.

[http://www.politicacriminal.cl/Vol_12/n_24/Vol12N24A9.pdf]

aunque lentamente, cada vez más relevancia en el ordenamiento chileno. Así se observa por ejemplo en las normas de la SVS sobre prevención del lavado de activos, en el notable proceso de elaboración de manuales internos de las empresas sobre el tratamiento de información aún no revelada pero sensible para el mercado, en los instructivos de la UAF sobre señales de alerta $\mathrm{o}$, ya fuera del derecho sancionatorio administrativo, en las guías de conducta elaboradas por la Fiscalía Nacional Económica. Todos estos documentos se encuentran además ampliamente difundidos en los respectivos portales web de los diferentes servicios.

La evolución en esta materia es auspiciosa y, hasta ahora, prudente. Pues siempre existe el riesgo de que los servicios se arroguen más facultades de las que tienen y pretendan establecer deberes que la ley no impone. En este sentido, es particularmente destacable el documento "Tipologías y señales de alerta de la lavado de activos en Chile" elaborado en 2012 por la UAF, en el cual se presentan los principales casos pertinentes y la forma como han sido resueltos por los tribunales.

El establecimiento de un derecho sancionatorio administrativo basado en la exigencia de modelos de cumplimiento eficaces tiene una consecuencia de la mayor importancia. En un derecho sancionatorio administrativo así configurado, la infracción administrativa consiste precisamente en la ausencia de un compliance efectivo. Esto implica, por un lado, que no es necesario establecer un vínculo de imputación directa -al modo del derecho penal- entre la empresa o el ejecutivo y la persona que concretamente cometió la infracción. Como contrapartida, las sanciones que se imponen a la empresa no corresponden a la comisión de la infracción, sino que están llamadas a compeler a la adopción o mejoramiento del modelo o programa (eventualmente con la amenaza de una sanción mayor en caso de que no se verifique).

Esta lógica es inseparable de la imposición de sanciones a personas jurídicas -en rigor, toda sanción contra una persona jurídica se basa únicamente en la ausencia de un compliance efectivo-, pero también es aplicable a las personas naturales en cuyas manos está el cúmulo de decisiones que implica la adopción de un modelo de cumplimiento efectivo.

Por último, antes de que intervenga el derecho sancionatorio administrativo tienen que haber fracasado los mecanismos preventivos y correctivos, como por ejemplo -en ámbitos particularmente sensibles y respecto de los ilícitos más graves- la certificación del modelo de cumplimiento por parte de entidades autónomas y aprobadas por la autoridad. Un sistema sancionatorio basado en modelos de cumplimiento facilita la aplicación de una enforcement pyramid, en el sentido apuntado más arriba.

\subsection{Prescripción y otros aspectos procesales}

En consideración a los fines del derecho sancionatorio administrativo, los plazos de prescripción de las infracciones deberían ser breves -lo indispensable para fiscalizar y procesar la infracción-, aunque no tan breves como los seis meses que rigen para las faltas penales. A pesar de que la aplicación de este plazo puede encontrarse actualmente 
VAN WEEZEL, Alex "Sobre la necesidad de un cambio de paradigma en el derecho sancionatorio administrativo".

justificada ante la ausencia de regulación ${ }^{83}$, no hay razones para dificultar el trabajo de la administración imponiéndole por ley plazos de prescripción establecidos en el derecho penal para los ilícitos de bagatela.

En lo procesal, es indispensable avanzar hacia un procedimiento unificado para todas las contravenciones. Es tal el caos imperante en el actual ordenamiento ${ }^{84}$, que se ha llegado a discutir en el foro si el plazo para reclamar de ciertas sanciones se cuenta conforme a las reglas del Código de Procedimiento Civil, a las de la Ley de Bases de los Procedimientos Administrativos, o si - a falta de norma expresa- habría que aplicar simplemente la regla general del Código Civil según la cual los plazos son de días corridos. Aunque se ha ido asentando cada vez más, el criterio conforme al cual se aplicaría supletoriamente el sistema de cómputo de la Ley $\mathrm{N}^{\circ} 19.880$ no pasa de ser, por el momento, una útil orientación.

En este contexto debe plantearse también, con sentido práctico y de realidad, el sistema de recursos y la relevancia del foro de apelación o reclamación que está llamado a garantizar la vigencia real del estado de derecho. La potestad que ejerce la autoridad sancionadora es una potestad administrativa y no jurisdiccional, lo que incide sustancialmente en la índole de los recursos para su control: el sistema de recursos debe hacerse cargo del cúmulo de potestades regladas (ilegalidad) y no regladas (desviación de poder) que inciden en un procedimiento sancionatorio. La situación actual, donde por lo general se reclama ante el juez de letras o ante la Corte de Apelaciones de Santiago en un procedimiento sumarísimo, resulta insatisfactoria, pues se reconoce a la autoridad administrativa un amplio margen de discrecionalidad so pretexto de un control externo que rara vez llega. Para comprobarlo, basta con revisar el destino de las reclamaciones contra sanciones administrativas, que difícilmente se explica por la perfección con que ellas son investigadas e impuestas ${ }^{85}$.

Probablemente sea adecuado un sistema que contemple reposiciones contra las resoluciones intermedias más relevantes y un recurso extraordinario contra el acto administrativo de término, que sea conocido por un tribunal de alzada especializado. En todo caso, el régimen debería prever una condena (¿forzosa en la última instancia?) en costas efectivas aplicable a ambas partes. Es un hecho que para el particular es caro en términos económicos, y muchas veces en términos de imagen, litigar contra la administración; pero el proceso también puede ser parte de los costos de un negocio que se ha concretado precisamente gracias a la

\footnotetext{
${ }^{83}$ Véase al respecto VALLEJO GARRETÓN, “Acerca del régimen supletorio de prescripción”, cit. nota n 24, pp. 281 y ss., con argumentos de disímil plausibilidad a favor de plazos de prescripción más extensos. En todo caso, la praxis legislativa y el régimen de plazos de la Ley $\mathrm{N}^{\circ} 19.880$ sugieren un plazo de prescripción en torno a los dos años.

${ }^{84}$ Una visión panorámica del problema en LARA, "Procedimientos de fiscalización/sanción", cit. nota $n^{\circ} 45$, pp. 283 y ss.

${ }^{85}$ No se encuentra disponible, hasta donde alcanzo, una estadística detallada al respecto. La afirmación contenida en el texto se basa en la observación del acontecer del foro y en los datos publicados por el Consejo de Defensa del Estado. Según el Balance de Gestión Integral de Defensa de esa entidad, durante el año 2015 el Consejo obtuvo un 94\% de sentencias favorables en asuntos contencioso administrativos. Los datos están disponibles en www.cde.cl. ROMERO, Alejandro, "Los privilegios probatorios de la Administración en la litigación pública”, en: ARANCIBIA, Jaime; ROMERO, Alejandro (Coords.), La prueba en la litigación pública, Santiago: Librotecnia, 2016, pp. 83 y ss., analiza en detalle estos datos y los relaciona con los privilegios procesales de la administración en la litigación pública.
} 
Polít. crim. Vol. 12, No 24 (Diciembre 2017), Art. 9, pp. 997-1043.

[http://www.politicacriminal.cl/Vol_12/n_24/Vol12N24A9.pdf]

infracción. Por otro lado, ocurre que para los funcionarios de la administración el proceso se convierte, a partir de cierto punto, en un costo ya asumido. Los funcionarios que lo impulsan no pagan este costo y tampoco lo hacen los jefes de servicio. Si a ello se suma que el control jurisdiccional es extraordinariamente tenue, la irresponsabilidad -en el sentido de ausencia de accountability - pasa a ser más que una mera sensación. Igual que en los demás aspectos tratados más arriba, la decisión sobre el sistema de recursos aplicable al derecho sancionatorio administrativo debería tomarse atendiendo a esta clase de cuestiones, y no en base a una supuesta asimilación ideológica entre el derecho contravencional y el derecho penal.

Hay muchos otros aspectos cuyo desarrollo es importante y necesario: introducir una gestión profesional y transparente de la oportunidad en la persecución, hoy solo incipiente por ejemplo, en los programas anuales y públicos de fiscalización contemplados en la Ley $\mathrm{N}^{\circ}$ 20.417-, para que no se pueda elegir en forma arbitraria a quién se fiscaliza o cuándo se fiscaliza; evaluar un concepto estadístico de causalidad para la imputación de resultados, allí donde su producción sea un requisito para la imposición de la sanción (esto podría evitar el uso de figuras de peligro abstracto allí donde no sea indispensable); considerar una exigencia de pura o mera evitabilidad individual, sin mayor precisión, en el plano de la imputación subjetiva, e incluso la introducción de algunos casos de strict liability perfectamente identificados- en ilícitos menores; adoptar una definición clara en materia de concurso de personas, por ejemplo, a favor de un concepto unitario de autor con una excepción legal para quien ha contribuido en muy menor medida a la realización de la infracción; definir si las sanciones solo se impondrán en caso de consumación; etc. Por razones obvias, estos aspectos no pueden ser desarrollados en este lugar.

\section{Síntesis}

1. El derecho sancionatorio administrativo y el derecho penal se parecen solo superficialmente. Son asuntos distintos y esto se manifiesta en las reglas sustantivas (grado de indeterminación de los presupuestos de la sanción, consideración de bagatelas, exigencias de imputación subjetiva, etc.), en las reglas procesales (oportunidad, régimen de la prueba, sistema recursivo, prescripción, etc.) y en los aspectos institucionales (investigación y sanción en una sola mano y a un relativo bajo costo).

2. Aunque se halle justificado por la configuración actual de las leyes y el déficit en la teoría administrativa de las sanciones, sería un error pretender extender por razones de principio las garantías penales al derecho sancionatorio administrativo. Este camino lleva a su inflación extensiva e intensiva, pero sin el costo de la justicia penal y por lo tanto sin la institucionalidad apropiada, lo que se traduce en garantías meramente nominales. Es decir, solo se daría una apariencia de legitimidad a lo que en realidad sería un enorme y disparatado derecho de policía. Por otro lado, la asimilación desnaturalizaría el derecho sancionatorio administrativo y le impediría lograr sus fines. Por lo tanto, el derecho sancionatorio administrativo debe configurarse de un modo muy diferente del que presenta en la actualidad: debe dejar un amplio espacio a acuerdos suspensivos del procedimiento, debe prever sanciones que impliquen mejoramiento de estándares y no meras transferencias 
VAN WEEZEL, Alex "Sobre la necesidad de un cambio de paradigma en el derecho sancionatorio administrativo".

de recursos al Fisco, debe poner el acento en los programas de cumplimiento, etc. En un derecho sancionatorio administrativo configurado realmente para conseguir sus fines de eficacia y buen funcionamiento de la regulación sectorial, basta con el régimen de garantías que emana del principio de necesidad de la sanción y de los principios fundamentales del debido proceso, incluyendo la previsibilidad de las sanciones.

3. El derecho sancionatorio administrativo debe servir para elaborar una especie de "pirámide de enforcement", aunque en un sentido algo distinto del que proponen los teóricos de la regulación sensible o responsiva. En el planteamiento aquí esbozado, la base de la pirámide debería formarse con muchos ilícitos que hoy son penales y que podrían pasar a ser administrativos y, por lo mismo, quedar sujetos a los mecanismos y al régimen descrito: ciertas zonas de ilicitud en el mercado de valores, en materia de libre competencia y de propiedad intelectual, algunas formas de administración desleal que hoy ni siquiera están sujetas a sanciones, etc. Así se puede reservar para el derecho penal los ilícitos más graves y, entonces, hacerlo seriamente, es decir, con capacidad real de persecución y con penas adecuadas, que excluyan en principio la aplicación de los regímenes legales pensados para las bagatelas o los ilícitos de escasa entidad. 
Polít. crim. Vol. 12, № 24 (Diciembre 2017), Art. 9, pp. 997-1043.

[http://www.politicacriminal.cl/Vol_12/n_24/Vol12N24A9.pdf]

\section{OBRAS CITADAS}

ACHENBACH, Hans; RANSIEK, Andreas; RÖNNAU, Thomas (Eds.), Handbuch Wirtschaftsstrafrecht, Heidelberg: C.F. Müller, $4^{\mathrm{a}}$ ed. 2015.

ARANCIBIA, Jaime, "El principio de necesidad de la sanción administrativa como potestad de ultima ratio", en: ARANCIBIA, Jaime; ALARCÓN, Pablo, Sanciones Administrativas, Santiago: Thomson Reuters, 2014, pp.129-147.

AYRES, Ian; BRAITHWAITE, John, Responsive Regulation, New York, Oxford: OUP, 1992.

BERMAN, Mitchell N., "Two Kinds of Retributivism", en: DUFF, R. A.; GREEN, Stuart P., Philosophical Foundations of Criminal Law, Oxford: OUP, 2011, pp. 433-457.

BERMÚDEZ, Jorge, "Fundamento y límites de la potestad sancionadora administrativa en materia ambiental", Revista de Derecho (Pontificia Universidad Católica de Valparaíso) XL (2013, $1^{\circ}$ Semestre), pp. 421-447.

BOUTAUD, Emilio, Constitucionalidad de los apremios personales en la jurisprudencia del Tribunal Constitucional, Memoria de Prueba para optar al grado de Licenciado en Ciencias Jurídicas y Sociales, U. Austral de Chile (sin fecha), accesible en http://cybertesis.uach.cl/tesis/uach/2014/fjb778c/doc/fjb778c.pdf [última visita 17.05.17].

CAHILL, Michael T., "Retributive Justice in the Real World", 85 Washington University Law Review (2008), pp. 816-870.

COFFEE, John, “'No Soul to Damn: No Body to Kick': An Unscandalized Inquiry into the Problem of Corporate Punishment", Michigan Law Review, Vol. 79, № 3 (1981), pp.386-459.

COLLADO, Rafael, "De la administrativización del derecho penal a la criminalización del derecho administrativo", en: ARANCIBIA, Jaime; ALARCÓN, Pablo, Sanciones Administrativas, Santiago: Thomson Reuters, 2014, pp. 541-565.

CORDERO QUINZACARA, Eduardo, "Los principios que rigen la potestad sancionadora de la Administración en el derecho chileno", Revista de Derecho (Pontificia Universidad Católica de Valparaíso) XLII (2014, 1 Semestre), pp. 399-439.

, Derecho Administrativo Sancionador, Santiago: Thomson Reuters, 2014.

CORDERO VEGA, Luis, "El decaimiento del procedimiento administrativo sancionador. Comentarios a las sentencias de la Corte Suprema del año 2010", en: VV.AA., Anuario de Derecho Público. Universidad Diego Portales, Santiago: Ediciones UDP, 2010, pp. 243-255.

CURY, Enrique, Derecho Penal, Parte General, Santiago: Ediciones Universidad Católica de Chile, $7^{\text {a }}$ ed. 2005.

FERNÁNDEZ, J.A., "Tribunal Constitucional y derecho penal: Un estudio crítico", Estudios Constitucionales, $\mathrm{N}^{\circ} 2$ (2014), pp. 187-238.

FISSE, Brent y BRAITHWAITE, John, "The Allocation of Responsibility of Corporate Crime: Individualism, Collectivism and Accountability”, Sydney Law Review, Vol. 11 (1988), pp. 444- 513.

GARCÍA CAVERO, Percy, "El principio del ne bis in ídem material en caso de concurrencia de pena y sanción administrativa", Política Criminal, Vol. 11, No 21 (Julio 2016), pp. 21-33. 
VAN WEEZEL, Alex "Sobre la necesidad de un cambio de paradigma en el derecho sancionatorio administrativo".

GARCÍA PALOMINOS, Gonzalo, "Modelo de protección en normas administrativas y penales que regulan el abuso de información privilegiada en la legislación chilena", Política Criminal, Vol. 8, no 15 (2013), pp. 23-63.

GÜRTLER, Franz; SEITZ, Helmut, en: GÖHLER, Erich, Ordnungswidrigkeitengesetz, München: C. H. Beck, $16^{\text {a }}$ ed. 2012.

GRUNER, Richard S., "Beyond Fines: Innovative Corporate Sentences under Federal Sentencing Guidelines", 71 Wash. U. L. Q. (1993), pp. 261-328.

HABERMAS, Jürgen, „Recht und Moral“, en: Faktizität und Geltung. Beiträge zur Diskurstheorie des Rechts und des demokratischen Rechtsstaats, Frankfurt a. M.: Suhrkamp, 1992.

COUSO, Jaime y HERNÁNDEZ, Héctor, Código Penal Comentado. Parte General, Santiago: LegalPublishing, 2011.

HUEPE, Fabián, "El problema de la discrecionalidad en la potestad sancionadora de la Administración. Su control a través del principio de razonabilidad", en: ARANCIBIA, Jaime; ALARCÓN, Pablo, Sanciones Administrativas, Santiago: Thomson Reuters, 2014, pp.167-186.

LARA, José Luis, "Procedimientos de fiscalización/sanción y Ley N 19.880: ¿Suficiencia de la supletoriedad", en: ARANCIBIA, Jaime; ALARCÓN, Pablo, Sanciones Administrativas, Santiago: Thomson Reuters, 2014, pp. 283-300.

LETELIER, Raúl, "Un paso adelante de la Corte Suprema, dos pasos atrás del Tribunal Constitucional: garantías penales y sanciones administrativas”, en El Mercurio Legal, 2.XII.2016.

LEWIS, Sebastián, "El solve et repete. Estudio de una regla que debe ser derogada", en: ARANCIBIA, Jaime; MARTÍNEZ, José I.; ROMERO, Alejandro (Coords.), Litigación pública, Santiago: Thomson Reuters, 2011, pp. 467-502.

LONDOÑO, Fernando, "Tipicidad y legalidad en el derecho administrativo-sancionatorio", Revista de Derecho (Valdivia), Vol. XXVII, N 2 (2014), pp. 147-167.

MAÑALICH, Juan Pablo, "El principio ne bis in idem frente a la superposición del derecho penal y el derecho administrativo sancionatorio", Política Criminal, Vol. 9, No 18 (2014), pp. 543-563.

MARTINS, Antonio, "Ein nachmetaphysisches Strafrecht? Gedanken zum retributiven Charakter der Strafe", Zeitschrift für Internationale Strafrechtsdogmatik 10/2014, pp. 514-521.

MOORE, Michael, “Justifying Retributivism”, 27 Israel Law Review (1993), pp. 15-49.

MÜHLENFELD, Leonhard, Die informelle Strafe im deutschen und europäischen Wirtschaftsstrafrecht, Berlin: Wissenschaftlicher Verlag Berlin, 2010.

NIETO MARTÍN, Adán, La responsabilidad penal de las personas jurídicas: un modelo legislativo, Madrid: Iustel, 2008.

NOVOA MONREAL, Eduardo, Curso de Derecho Penal Chileno, I, Santiago: Editorial Jurídica de Chile, reimpresión de la $3^{\mathrm{a}}$ ed. de 1960, 2005.

OSORIO, Cristóbal, Manual de procedimiento administrativo sancionador. Parte General, Santiago: Thomson Reuters, 2016.

PAREJO, Luciano, "Algunas reflexiones sobre la necesidad de la depuración del status de la sanción administrativa", Revista General de Derecho Administrativo, Vol. 36 (2014), pp. 1-26. 
Polít. crim. Vol. 12, № 24 (Diciembre 2017), Art. 9, pp. 997-1043.

[http://www.politicacriminal.cl/Vol_12/n_24/Vol12N24A9.pdf]

PAWLIK, Michael, Das Unrecht des Bürgers, Tübingen: Mohr Siebeck, 2012.

RAJEVIC, Enrique, "La sinuosa reserva legal de la potestad sancionatoria y los privados que ejercen funciones públicas: Navegando entre las relaciones de sujeción especial y la contractualización", en: ARANCIBIA, Jaime; ALARCÓN, Pablo, Sanciones Administrativas, Santiago: Thomson Reuters, 2014, pp. 89-105.

RIOFRÍO MARTÍNEZ-VILLALBA, J. C., "Alcance y límites del principio de proporcionalidad", Revista Chilena de Derecho, Vol. 43, № 1 (2016), pp. 283-309.

ROMERO, Alejandro, "Los privilegios probatorios de la Administración en la litigación pública”, en: ARANCIBIA, Jaime; ROMERO, Alejandro (Coords.), La prueba en la litigación pública, Santiago: Librotecnia, 2016, pp. 83-114.

SÁNCHEZ, Carlos, Problemas de determinación de la pena en la Ley $N^{\circ} 20.393$, Universidad de Chile, memoria para optar al grado académico de Licenciado en Ciencias Jurídicas y Sociales, Santiago, 2013.

SILVA SÁNCHEZ, J. M., "Eficiencia y derecho penal", Anuario de Derecho Penal y Ciencias Penales, t. 49 (1996), pp. 93-128.

La expansión del derecho penal, Madrid: Civitas, $2^{\text {a }}$ ed., 2001.

SOTO DELGADO, Pablo, "Sanciones administrativas como medidas de cumplimiento del Derecho: un enfoque funcional y responsivo aplicado al régimen sancionatorio ambiental", Revista Ius et Praxis, Año 22, № 2 (2016), pp. 189-226.

"Un mal caso para flexibilizar la tipicidad en el derecho administrativo sancionador. Comentario al fallo 'Empresa de Servicios Sanitarios ESSBIO S.A. con Seremi de Salud del Biobío" de la Corte suprema, Rol n 7397-2012", Revista Chilena de Derecho, Vol. 42, núm. 2 (2015), pp. 701-714.

TEUBNER, Günther, Recht als autopoietisches System, Frankfurt a. M.: Suhrkamp, 1989.

VALLEJO GARRETÓN, Rodrigo, "Acerca del régimen supletorio de prescripción aplicable a las infracciones y sanciones administrativas", Revista de Derecho (Pontificia Universidad Católica de Valparaíso), XLVII (2 semestre, 2016), pp. 281301.

VAN WEEZEL, Alex, Delitos Tributarios, Santiago: Editorial Jurídica de Chile, 2007. 2008.

Error y mero desconocimiento en derecho penal, Santiago: Legal Publishing,

La garantía de tipicidad en la jurisprudencia del Tribunal Constitucional, Santiago: Abeledo Perrot, 2011.

,"Mandato de determinación de los tipos penales: una garantía en peligro", Revista Penal México $\mathrm{N}^{\circ} 5$ (2013), pp. 207-216.

VÁSQUEZ, M. Fernanda, "Caso LAN y uso de información privilegiada: un análisis de la correcta delimitación de las infracciones legales", Revista Ius et Praxis, Año 16, $\mathrm{N}^{\circ} 2$ (2010), pp. 461-484.

WALTER, Tonio, Der Kern des Strafrechts. Die allgemeine Lehre vom Verbrechen und die Lehre vom Irrtum, Tübingen: Mohr Siebeck, 2006.

WITTIG, Petra, Wirtschaftsstrafrecht, München: C.H. Beck, $3^{\text {a }}$ ed. 2014. 